Article

\title{
Study on the Relationship between Snowmelt Runoff for Different Latitudes and Vegetation Growth Based on an Improved SWAT Model in Xinjiang, China
}

\author{
Yongchao Duan ${ }^{1}$, Min Luo ${ }^{2}$, Xiufeng Guo ${ }^{1}$, Peng Cai ${ }^{1, * \mathbb{D}}$ and Fu Li ${ }^{1, *}$ \\ 1 College of Atmospheric and Remote Sensing, Binjiang College of Nanjing University of Information Science \& \\ Technology, Wuxi 214105, China; duanyongchao13@mails.ucas.ac.cn (Y.D.); guoxf_88@163.com (X.G.) \\ 2 College of Geographical Science, Inner Mongolia Normal University, Hohhot 010022, China; \\ luomin@imnu.edu.cn \\ * Correspondence: caipeng13@mails.ucas.ac.cn (P.C.); muzibaotian@163.com (F.L.); \\ Tel.: +86-510-80560151 (P.C.); +86-510-80560151 (F.L.)
}

Citation: Duan, Y.; Luo, M.; Guo, X.; Cai, P.; Li, F. Study on the Relationship between Snowmelt Runoff for Different Latitudes and Vegetation Growth Based on an Improved SWAT Model in Xinjiang, China. Sustainability 2021, 13, 1189 https://doi.org/10.3390/su13031189

Received: 17 December 2020

Accepted: 21 January 2021

Published: 23 January 2021

Publisher's Note: MDPI stays neutral with regard to jurisdictional claims in published maps and institutional affiliations.

Copyright: (C) 2021 by the authors Licensee MDPI, Basel, Switzerland. This article is an open access article distributed under the terms and conditions of the Creative Commons Attribution (CC BY) license (https:// creativecommons.org/licenses/by/ $4.0 /)$.

\begin{abstract}
Rivers located in high altitude mountainous areas provide a large number of water resources and are also high-risk areas for seasonal snow melt floods. The accurate calculation and simulation of snow melting processes can provide reliable data for flood disaster prediction. In order to make the Soil and Water Assessment Tool (SWAT) model more suitable for high altitude mountainous areas, the effect of the daily accumulated temperature on the precipitation pattern and snow melting is fully considered. Applying the modified model to three mountain systems with different latitudes in Xinjiang can not only improve our understanding of the characteristics of snowmelt flooding but can also be used to test the applicability of the modified model. Through comparison, it was found that the simulation accuracy of the modified model of the flood peak value was improved by $56.19 \%$. The correlation coefficient between the Normalized Difference Vegetation Index (NDVI) and snowmelt increased from 0.27 to 0.68 . This study provides a new method for accurately understanding the process of snowmelt runoff in the mountainous area and provides new insights into the effects of snowmelt runoff on vegetation growth at different latitudes.
\end{abstract}

Keywords: SWAT model; snowmelt; floods; accumulated temperature; NDVI

\section{Introduction}

Seasonal snow accumulation and snow melt are common and important natural laws in high-altitude mountainous areas around the world [1,2]. Due to global climate change [3-8], glaciers and snow cover in arid areas were shrinking faster and more sensitive to climate change [9]. In arid and semi-arid areas, the contribution rate of snowmelt runoff to rivers reaches more than $75 \%$ in spring [10]. Snowmelt is an extremely important water resource and plays an exceedingly important role in the rational utilization of water resources. However, while providing abundant water for rivers, it is also very likely to cause snowmelt floods [11-13]. Xinjiang is a representative arid and semi-arid region with a large latitude span and complex topographic conditions. The Altai Mountains, Tianshan Mountains, and Kunlun Mountains are located at different latitudes from north to south. There is a large amount of snow in the high altitude areas of these three mountain systems [12,14-20], which provides important water sources for regional ecosystem stability and food security. By studying the distribution of extreme hydrological events in Xinjiang, Sun et al., found that the frequency of disasters in the northwest was significantly higher than that in the southeast, and there was a downward trend to the southeast [21]. However, snowmelt floods also cause a large number of deaths and property losses every year. With the development of the Chinese economy, more and more attention has been paid to the prevention and control of flood disasters, and many resources have been invested. Any 
effective disaster prevention needs to be based on accurate predictions. Therefore, it is necessary to calculate and evaluate the amount of water released by snow and glaciers in alpine regions.

Ecosystems in arid and semi-arid regions are relatively fragile, and the sparse vegetation in the mountains and numerous rocks demonstrate the sensitivity and vulnerability of the ecological environment in these areas [22]. As one of the representative arid regions, the sensitive response of ecosystem in Xinjiang to climate change has also attracted the attention of scholars. As one of the representative arid regions, the sensitive response of ecosystem in Xinjiang to climate change has also attracted the attention of scholars. Zhang et al., found that major natural vegetation cover types in Xinjiang were sensitive to the climate change over the past 18 years. Xinjiang has experienced the warming and wetting trends (although not co-located) [23]. Due to the scarcity of precipitation, the main water source for vegetation growth comes from the snow stored in the winter. The snowmelt replenishes the soil moisture and provides sufficient moisture for the spring vegetation. Few comparative studies have been conducted on the relationship between vegetation growth and snowmelt runoff in alpine areas [24]. The characteristics of snowmelt runoff at different latitudes and in different watersheds and the comparison with vegetation growth can help us to better understand the effects of snowmelt runoff on vegetation growth in different areas and can also make up for the lack of research in this area.

At present, in order to simulate snow melting runoff, many snowmelt models have been developed, ranging from a simple temperature-index model such as degree-day factor to a complete energy balance model $[25,26]$. A model of the thermal and mass coupling transport in snow was proposed, and a sensitivity analysis of the parameters in the model was carried out by Tuteja et al. [27]. Fernandez et al., established a snow melt model based on the energy balance theory [28]. The energy balance of the snow surface and the entire snow layer was used to predict the snow surface temperature and the freezing depth and to accurately reproduce the development and melting process of the seasonal snow cover [28,29]. Herrero et al., developed a new mass and energy balance snowmelt point model and applied it to the Sierra Nevada Mountains, emphasizing the impact of evapotranspiration on the snowmelt process [30]. As a classical and mature hydrological model, the Soil and Water Assessment Tool (SWAT) model has been applied to high-altitude mountainous areas for the calculation of snowmelt runoff. Debele et al., compared the performance of the simple snow melting calculation methods based on the physical energy and temperature index of three locations on two different continents using the SWAT model [25]. Fontaine modified the SWAT model by improving the hydrological and atmospheric processes and applied it to the simulation of snow melting runoff in mountain areas with high elevations [31]. Kazi et al., have evaluated the stream flow modeling in a highly managed mountainous glacier watershed using temperature index approach of SWAT without elevation bands, the results of implementing elevation bands were better than without elevation bands [32]. The results showed slight improvement in runoff simulation and significant improvement in simulated mass balance when considering elevation in the research of glacier mass balance simulation using SWAT distributed snow algorithm [33]. Soni $\mathrm{M}$ et al., compared and accessed model simulated snowpack and snowmelt at different elevation bands with snow survey data available for the Canyonville reservoir watershed, SWAT indicated more precipitation falling as rain, increased and earlier snowmelt, and a reduced snowpack leading to a change in the pattern of stream flow, particularly during winter and early spring [34]. Three snowpack estimation approaches, the lumped-parameter temperature index approach from the Generalized Watershed Loading Function (GWLF) watershed model, a spatially distributed temperature index (SDTI) model, and the spatially distributed NOAA Snow Data Assimilation System (SNODAS) product were compared and tested by Elliot $\mathrm{M}$ et al. [35]. All three snowpack estimation approaches, performed well in estimating basin-wide snow water equivalent for most of the basins studied. In order to assess the climate-change effects on stream flow, the simulated stream flow from the calibrated Ground-water/Surface-water FLOW (GSFLOW) model 
and other basin characteristics were used as input to the one-dimensional Stream-Network Temperature (SNTEMP) model to simulate daily stream temperature in selected tributaries in the watershed [36].

However, few studies have been conducted on the differences between the calculated snowmelt runoff in different latitude alpine regions and its relationship to the basin ecology Olanrewaju et al., compared the evapotranspiration (ET) from the MODIS remotely sensed ET dataset (MOD16) with the ET estimates from a SWAT hydrological model on graduated spatial scales at different spatial scales. Based on the results of the study, the scale of $4 \mathrm{~km}^{2}$ for catchment-scale evapotranspiration is suggested in complex terrain [37]. During the input of meteorological data in the SWAT model, the precipitation type was only input as one type, and there was no distinction between rainfall and snowfall, which affected the precision of snowmelt calculation and model simulation. Therefore, by increasing the temperature judgment conditions, the form discrimination of rainfall and snowfall was carried out first when the precipitation data was input. In this study, the accumulated temperature condition and snow melting accumulated temperature condition were determined by adding a precipitation form, so the simulation of the snow melting process in alpine mountainous areas provided by the model is more accurate. In order to compare the differences in the snowmelt runoff in high-altitude mountainous areas at different latitudes, the SWAT model of the modified snowmelt module was used to simulate and compare the snowmelt runoff of the representative medium and small rivers in three major mountain ranges in Xinjiang. The influence of precipitation condition of the rain and snow separation on the runoff and hydrological processes in high altitude mountainous areas was fully considered. Combined with the relationship between the amount of snowmelt and the runoff and Normalized Difference Vegetation Index (NDVI), the differences in vegetation growth in the watersheds were compared, and the impact of snowmelt runoff on the regional ecology was quantitatively analyzed.

\section{Materials and Methods}

\subsection{Description of the Study Area}

Xinjiang is located in the arid and semi-arid region of Western China. It contains three mountain ranges and two basins. The Altai Mountains are located in the northern part of Xinjiang, the Tianshan Mountains are located in the middle, and the Kunlun Mountains are located in the south. The Junggar Basin in Northern Xinjiang and the Tarim Basin in Southern Xinjiang are the two major basins $[15,20,38]$. The terrain in each mountain system is complex, and the high altitude areas contain large areas of snow cover. A representative river basin was selected as the research object of each mountain system. The Daqing River Basin (DQR) is located in the middle of the Altai Mountains. Its elevation is between $1271 \mathrm{~m}$ and $3622 \mathrm{~m}$, and the watershed area is $1626.46 \mathrm{~km}^{2}$. The Kaiken River Basin (KKR) is located in the eastern part of the northern slope of the Tianshan Mountains. Its altitude ranges from $1498 \mathrm{~m}$ to $3964 \mathrm{~m}$, and its drainage area is $382.18 \mathrm{~km}^{2}$. The Heizi River Basin (HZR) is located on the southern slope of the Tianshan Mountains, with elevations of $1171 \mathrm{~m}$ and $4784 \mathrm{~m}$ and a basin area of $4619.76 \mathrm{~km}^{2}$. The Pishan River Basin (PSR) is located on the northern slope of the Kunlun Mountains, with an area of $1953.46 \mathrm{~km}^{2}$ and an elevation range of 1988-6291 $\mathrm{m}$ (Figure 1). These four rivers are medium and small rivers in high elevation mountainous areas, and thus, they are representative watersheds for snowmelt floods. In the non-snowmelt season, snowfall begins to accumulate in high altitude mountain areas. In spring, the temperature increases and the snow melts, which coincides with the high-frequency period of snowmelt floods. 

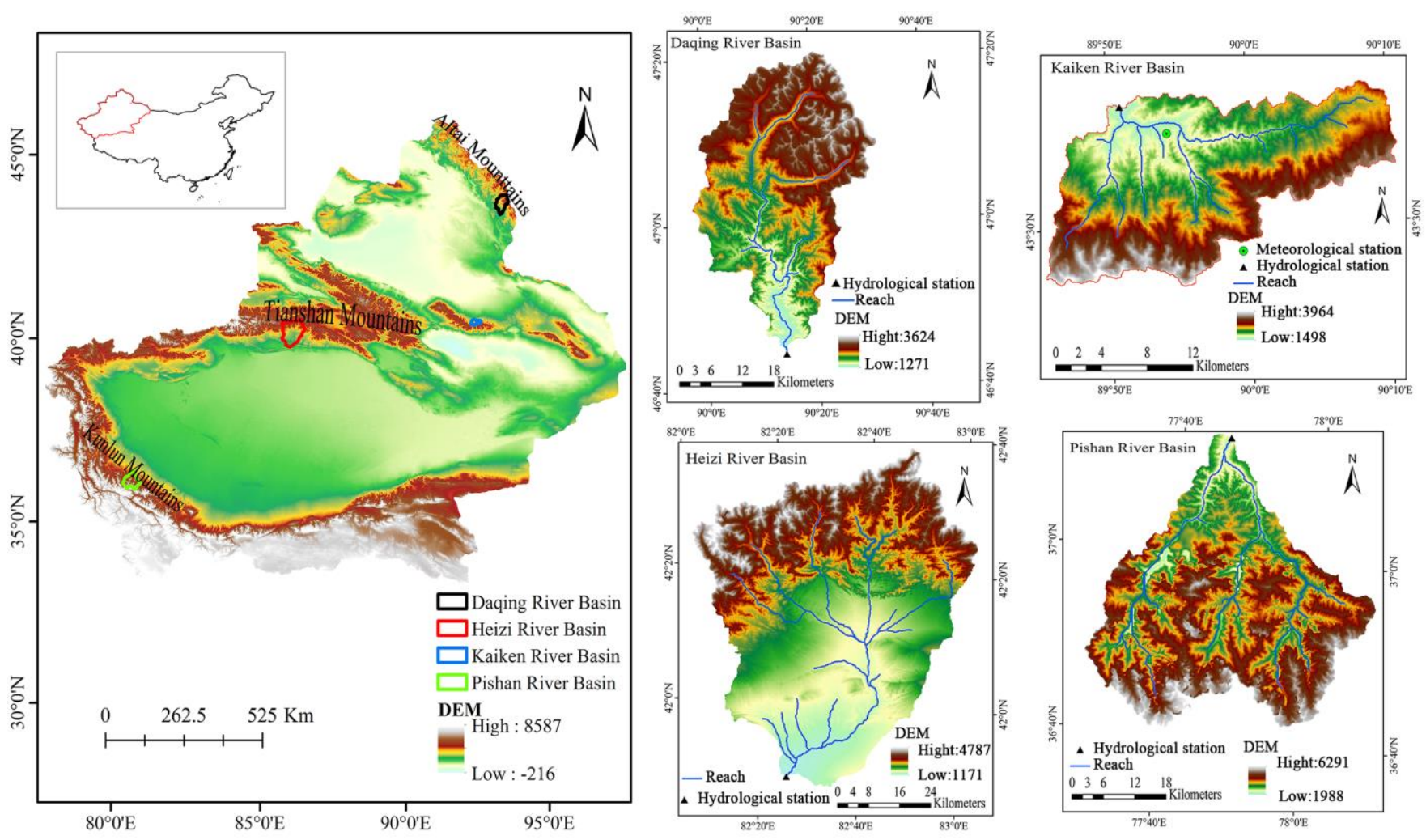

Figure 1. Locations of four rivers in the Xinjiang area.

\subsection{Materials}

The data collection and preparation were the first steps in the model-driven process. In addition, the types of model data were mainly divided into basic data and observation data. The basic data mainly include a digital elevation model (DEM), land use and land cover data (LUCC), and soil type data, while the observation data mainly came from the meteorological stations and hydrological stations in the basin. The $30 \mathrm{~m}$ DEM data were obtained from the Shuttle Radar Topography Mission's (SRTM) official website (http:/ / srtm.csi.cgiar.org/) and were applied to building the model. The spatial resolution of the LUCC data and the soil type data is both $30 \mathrm{~m}$. The data were obtained from websites (https:/ / www.usgs.gov/products/data-and-tools/real-time-data/remote-landsensing-and-landsat), the visual interpretation of imagery, and the China Soil Category Data Network (https:/ / geodata.pku.edu.cn/). The NDVI reflects the growth of vegetation. The NDVI data were calculated using 8-day MOD09Q1 data (https: / / modis.gsfc.nasa.gov / data/dataprod/mod09.php).

The basic information for the four rivers is shown (Table 1). According to the observation data collected from 2006 to 2011, the average daily temperature and the average daily discharge of the DQR were $2.59{ }^{\circ} \mathrm{C}$ and $15.74 \mathrm{~m}^{3} / \mathrm{s}$, respectively. The daily temperature of the KKR was $10.95^{\circ} \mathrm{C}$ according to the meteorological station data collected from 2006 to 2011. By calculating the hydrological observation data, the average daily discharge of the basin was $4.54 \mathrm{~m}^{3} / \mathrm{s}$. The average daily temperature of the PSR on the southern slope of the Tianshan Mountains was $10.47^{\circ} \mathrm{C}$ from 2008 to 2011, and the average river discharge was $13.67 \mathrm{~m}^{3} / \mathrm{s}$. The average daily temperature of the PSR in the Kunlun Mountains was $13.65{ }^{\circ} \mathrm{C}$ from 2006 to 2011 . The average daily runoff observation data show that the average daily temperature was $16.18 \mathrm{~m}^{3} / \mathrm{s}$. 
Table 1. Basic information about four basins.

\begin{tabular}{cccccccc}
\hline Name & $\begin{array}{c}\text { Area } \\
\left.\mathbf{k m}^{2}\right)\end{array}$ & $\begin{array}{c}\text { Watershed } \\
\text { Center Lati- } \\
\text { tude(Degree) }\end{array}$ & $\begin{array}{c}\text { Average } \\
\text { Altitude }(\mathbf{m})\end{array}$ & $\begin{array}{c}\text { Maximum } \\
\text { Temperature } \\
\left({ }^{\circ} \mathbf{C}\right)\end{array}$ & $\begin{array}{c}\text { Minimum } \\
\text { Temperature } \\
\left({ }^{\circ} \mathbf{C}\right)\end{array}$ & $\begin{array}{c}\text { Average Annual } \\
\text { Precipitation } \\
(\mathbf{m m})\end{array}$ & $\begin{array}{c}\text { Average Daily } \\
\text { Discharge }\left(\mathbf{m}^{3} / \mathbf{s}\right)\end{array}$ \\
\hline $\begin{array}{c}\text { Daqing River } \\
\text { Basin }\end{array}$ & 1626.46 & $47.0 \mathrm{~N}$ & 2447.0 & 9.75 & -4.56 & 199.32 & 15.74 \\
$\begin{array}{c}\text { Kaiken River } \\
\text { Basin }\end{array}$ & 382.18 & $43.5 \mathrm{~N}$ & 2731.0 & 17.65 & 4.25 & 221.89 & 4.54 \\
$\begin{array}{c}\text { Heizi River } \\
\text { Basin }\end{array}$ & 4619.76 & $42.0 \mathrm{~N}$ & 2977.5 & 17.29 & 3.65 & 147.05 & 13.67 \\
$\begin{array}{c}\text { Pishan River } \\
\text { Basin }\end{array}$ & 1953.46 & $36.5 \mathrm{~N}$ & 4139.5 & 20.24 & 7.06 & 58.52 & 16.18 \\
\hline
\end{tabular}

\subsection{Methodology}

The SWAT model is a conceptual, physically based, semi-distributed model developed by the United States Department of Agriculture, Agricultural Research Service (USDAARS) [39]. The original purpose of model development was to predict the long-term effects of land management on water, sediment, and chemicals under the complex and variable soil types, land use patterns and management practices in large watersheds [40]. There are six modules integrated into the model, including the snow melting, surface runoff, return flow, evapotranspiration, infiltration, underground runoff. The Digital Elevation Model (DEM) is used as the basic data to divide the river channel. The land use and land cover change data, soil type data, and meteorological data are the basic data-driven by the model. In the calculation of the model, the Hydrologic Response Units (HRUs) are divided according to the unique soil and land use types and slopes [25,31]. Each HRU is calculated separately and finally collected into the sub-basin. In the snow melting module of the SWAT model, the algorithm used is the degree-day factor algorithm. The influence of temperature was fully applied to hydrological processes and melting processes [41]. The SWAT model are also commonly used for pollutant migration assessment, water quality assessment, and water resource management [42].

\subsubsection{The Model Modification Method}

In this study, the modification of the original SWAT model was mainly focused on the determination of the precipitation patterns and snow melting conditions. In order to make the SWAT model more suitable for high altitude mountainous areas and to highlight the importance of the accumulated temperature to the precipitation patterns and snowmelt conditions, a new accumulated temperature threshold was added to the determination of the precipitation pattern (SFTMP_A), which divides the precipitation pattern into rainfall and snowfall, as shown in Figure 2. When the maximum temperature and the daily accumulated temperature ( $\left.T \_a\right)$ reach the set threshold at the same time, the precipitation pattern was determined to be rainfall, while all other cases were determined to be snowfall. In the snow melt calculation, the comparison of the snow melt using the maximum daily temperature (T_m) alone could not highlight the characteristics of a snow melting flood, and there was a certain deviation in the calculation of the amount of snow melt. The effect of the accumulated temperature on snow melting can be fully considered by adding a new daily accumulated temperature snow melting threshold based on the maximum temperature. 


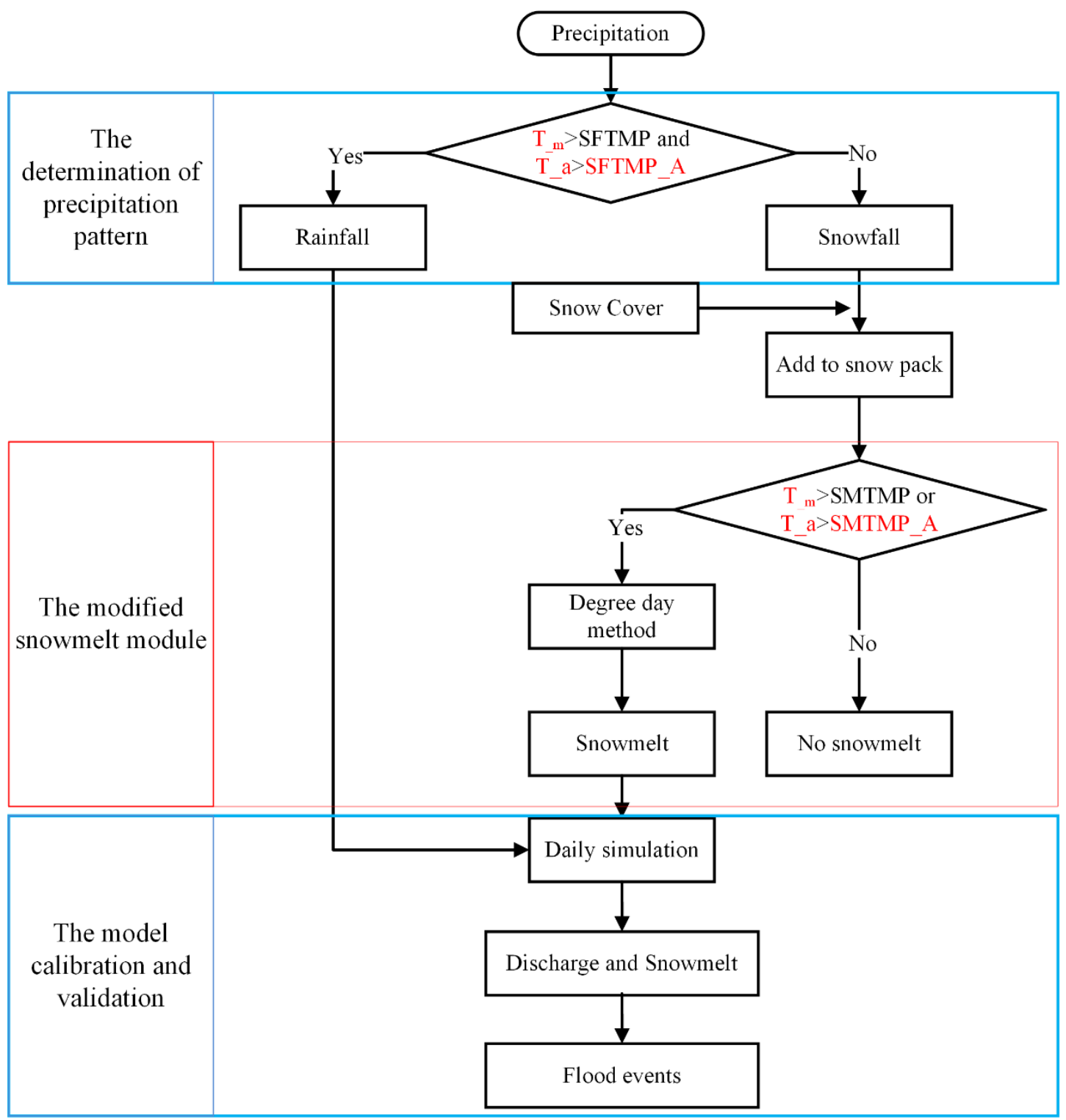

Figure 2. Research technology roadmap.

The temperature during the day generally increases in the morning, reaches the maximum for the day at noon, and decreases gradually until the lowest temperature is reached. Therefore, the temperature changes throughout the day can be approximately regarded as a sinusoidal curve. The temperature $(\mathrm{T})$ at any time of day can be expressed by Equation (1):

$$
T=\left(T_{m}-T_{m n}\right) \sin t+T_{m n} \quad 0 \leq t \leq \pi
$$

where $t$ represents the corresponding radian value at any time during the 24-h day, and $T_{m n}$ is the daily minimum temperature. When calculating the daily accumulated temperature, the integral method was used to calculate the accumulated temperature when the temperature was greater than $0{ }^{\circ} \mathrm{C}$. There was no snowmelt when the temperature was less than $0{ }^{\circ} \mathrm{C}$, so it was meaningless for the temperature integral of less than 0 . When the minimum temperature was greater than $0{ }^{\circ} \mathrm{C}$ in a day, we used Equation (2) to calculate the accumulated temperature:

$$
T=\int_{0}^{\pi}\left(T_{m x}-T_{m n}\right) \sin t+T_{m n} d t 0 \leq t \leq \pi
$$


When the minimum temperature was less than $0{ }^{\circ} \mathrm{C}$ for a day, but the maximum temperature was greater than $0{ }^{\circ} \mathrm{C}$, first, we determined the radian corresponding to the time when the temperature was equal to $0^{\circ} \mathrm{C}$, and we only calculated the accumulated temperature for the part of the day with a temperature of greater than $0{ }^{\circ} \mathrm{C}$. The equation used for this calculation is

$$
T=\int_{\sin ^{-1}\left(\frac{-T_{m n}}{T_{m x}-T_{m n}}\right)}^{\pi-\sin ^{-1}\left(\frac{-T_{m n}}{T_{m n}}\right)} T_{m x} \sin t d t, \sin ^{-1}\left(\frac{-T_{m n}}{T_{m x}-T_{m n}}\right) \leq t \leq \pi-\sin ^{-1}\left(\frac{-T_{m n}}{T_{m x}-T_{m n}}\right) 0 \leq t \leq \pi
$$

\subsubsection{Model Calibration, Validation, and Sensitivity Analysis}

The most important and difficult problem in the study of runoff in high altitude mountainous areas was verification, because the runoff observation in mountainous areas was not perfect, and the available runoff observation data was difficult to obtain. In this study, 2008-2011 was selected as the research periods, 2008 and 2009 were the warm-up periods of the model, 2010 as the calibration period, and 2011 as the validation period. The daily runoff simulation and comparative study were carried out on the four rivers at the same periods. Some parameters which have great influence on snow melt and runoff simulation are selected as key calibration targets shown in the Table 2.

Table 2. Important parameters in the model calibration process.

\begin{tabular}{|c|c|c|c|}
\hline File Extension & Parameter & Description & Range of Values \\
\hline. $\mathrm{bsn}(\mathrm{New})$ & SFTMP_A & Snowfall accumulated temperature & $0-40$ \\
\hline. $\mathrm{bsn}(\mathrm{New})$ & SMTMP_A & Snowmelt accumulated temperature & $0-40$ \\
\hline .bsn & SFTMP & Snowfall temperature & -20 to 20 \\
\hline.$b s n$ & SMTMP & Snow-melt base temperature & -20 to 20 \\
\hline.$b s n$ & SMFMX & Maximum melt rate for snow during the year & $0-20$ \\
\hline .bsn & SMFMN & Minimum melt rate for snow during the year & $0-20$ \\
\hline.$b s n$ & TIMP & Snowpack temperature lag factor & $0-1$ \\
\hline.$b s n$ & SNOCOVMX & Minimum snow water content corresponding to $100 \%$ snow cover & $0-500$ \\
\hline.$b s n$ & SFTMP & Snowfall temperature & -40 \\
\hline.$b s n$ & SURLAG & Surface runoff lag time & $0.05-24$ \\
\hline gw & ALPHA_BF & Base flow alpha factor (days) & $0-1$ \\
\hline gw & GW_DELAY & Groundwater delay (days) & $0-500$ \\
\hline .gw & GWQMN & $\begin{array}{l}\text { Threshold water depth in the shallow aquifer required for return } \\
\text { flow to occur (mm) }\end{array}$ & $0-5000$ \\
\hline.$g w$ & SHALLST & Initial water depth in the shallow aquifer (mm) & $0-50,000$ \\
\hline gw & GW_REVAP & Groundwater "revamp" coefficient & $0.02-0.2$ \\
\hline .mgt & $\mathrm{CN} 2$ & SCS runoff curve number & $35-98$ \\
\hline .ohru & OV_N & Manning's " $n$ " value for overland flow & $0.01-30$ \\
\hline .ohru & ESCO & Soil evaporation compensation factor & $0-1$ \\
\hline .ohru & EPCO & Plant uptake compensation factor & $0-1$ \\
\hline .rte & CH_N2 & Manning's " $n$ " value for the main channel & -0.01 to 0.3 \\
\hline .rte & $\mathrm{CH} \_\mathrm{K} 2$ & Effective hydraulic conductivity in main channel alluvium & -0.01 to 500 \\
\hline sol & SOL_K & Saturated hydraulic conductivity & 0-2000 \\
\hline .sol & SOL_AWC & Available water capacity of the soil layer & $0-1$ \\
\hline .sub & PLAPS & Precipitation lapse rate & -20 to 20 \\
\hline.$s u b$ & TLAPS & Temperature lapse rate & -10 to 10 \\
\hline sub & CH_N1 & Manning's " $n$ " value for the tributary channels & $0.01-30$ \\
\hline sub & CH_K1 & Effective hydraulic conductivity in tributary channel alluvium & $0-300$ \\
\hline.$s u b$ & SNO_SUB & Initial snow water content & $0-150$ \\
\hline
\end{tabular}

When the accuracy of the simulation results of the model was evaluated, the measured data were compared with the simulated data. The corresponding evaluation parameters and indicators were chosen and used for the evaluation. The Nash-Sutcliffe efficiency (NSE) 
and the percent bias (PBIAS) were used to test the accuracy of the simulation produced by the model. The equation used to calculate the NSE is

$$
N S E=1-\frac{\sum_{i=1}^{n}\left(Q_{s i m, i}-Q_{o b s, i}\right)^{2}}{\sum_{i=1}^{n}\left(Q_{o b s, i}-\bar{Q}_{o b s}\right)^{2}} .
$$

The maximum value of NSE was 1 . The closer the NSE to 1, the closer the result of the model simulation to the measured value, and the higher the accuracy. The equation used to calculate the PBIAS is

$$
\text { PBIAS }=100 \times \frac{\sum_{i=1}^{n}\left(Q_{s i m, i}-Q_{o b s, i}\right)}{\sum_{i=1}^{n} Q_{o b s, i}} .
$$

The PBIAS was used to measure whether the simulation results of the model were overestimated or underestimated compared with the measured data. When the PBIAS was greater than 0 , the simulation results were overestimated, and when the PBIAS was less than 0 , the results were underestimated. The closer the PBIAS to 0 , the higher the accuracy of the simulation results, and the closer the results to the measured values. $Q_{s i m, i}$ is the model simulated value on the $i_{\text {th }}$ day; and $Q_{o b s, i}$ is the observation value on the $i_{\text {th }}$ day. $\bar{Q}_{o b s}$ was the average value of all of the observation data, $i$ was any day in the simulation period, and $\mathrm{n}$ was the total number of simulated days. In general, the two indexes were used together to evaluate the accuracy of the model simulation results.

In the calibration of the parameters of the model, the Soil and Water Assessment Tool Calibration and the Uncertainty Procedure (SWAT-CUP) [43-47] was used to simulate the model hundreds or thousands of times in order to determine the optimal combination of parameters [22]. The NSE and PBIAS indicators were used to evaluate the simulation results, and a combination of satisfactory parameters was obtained. The global sensitivity analysis method in the sequential uncertainty fitting (SUFI-2) [48-50] was used for the parameter sensitivity analysis. The $T$-states and $p$-values were two important indicators of the sensitivity analysis. The greater the absolute value of the $T$-states, and the closer the $p$-values to 0 , the more sensitive the parameters. Through this method, the degree of influence of each parameter on the simulation results was determined, and the insensitive parameters were deleted, the calculation efficiency and accuracy of the model were improved, and the uncertainty of the parameters was minimized at the same time.

\section{Results}

\subsection{The Performsnce of the Daily Model Simulation}

In order to show the effect of the model modifications, the evaluation indicators of the simulation results before and after the model modification were calculated for basins with different elevations, as shown in Table 3. Two indicators, the NS and PBIAS, were used to compare the simulation results of the four rivers in the calibration, validation, and overall periods. In the DQR, the NS coefficient in the validation period was the smallest (0.65). However, in the simulation results of the modified model, the value of the NS coefficient increased to 0.76 , which is a significant improvement. In the other two periods, the NS coefficient was improved by the model modification. In three periods, the model showed an underestimation before and after the modification. The maximum value of the PBIAS was 37.36 in the validation period, but the accuracy was improved to 15.07 by the modified model. In the KKR, the NS value was between 0.62 and 0.67 for the original model simulation results, but through the modification, the NS value was increased to a maximum of 0.82. During the overall and calibration periods, the model simulation results showed an overestimation phenomenon, while it showed underestimation in the validation period. The maximum PBIAS of the original model was 13.62 in the validation period. Through the model modification, it increased to 7.94 , and a PBIAS minimum of -4.05 was achieved for the simulated results of the modified model. The minimum NS value of the HZR also occurred in the validation period, which was 0.68 of the simulation result of the 
original model. Through the modification of the snow melting module, the NS value was increased by 0.04 . The PBIAS value reveals that the simulation result of the original model was underestimated in three periods, and the simulation result of the modified model was overestimated, but the PBIAS value of the modified model was significantly different than the original model. Although the original model produced good simulation results in the PSR in the Kunlun Mountains, the minimum NS coefficient was 0.74 , and the minimum PBIAS was 12.4, which also indicate underestimation. However, the modified simulation results of the model have a significantly improved basis compared to the original, i.e., the maximum value of the NS reached 0.88 , and the minimum value of the PBIAS was 3.56 . Therefore, the modification significantly improved the accuracy of the simulation results.

Table 3. Changes in the evaluation indexes of the simulation results before and after the modification of the different basins.

\begin{tabular}{|c|c|c|c|c|c|c|c|c|c|c|c|c|}
\hline \multirow{3}{*}{ Basins } & \multicolumn{6}{|c|}{ NS } & \multicolumn{6}{|c|}{ PBIAS } \\
\hline & \multicolumn{2}{|c|}{$\begin{array}{c}\text { Overall } \\
(2010-2011)\end{array}$} & \multicolumn{2}{|c|}{ Calibration (2010) } & \multicolumn{2}{|c|}{ Validation (2011) } & \multicolumn{2}{|c|}{$\begin{array}{c}\text { Overall } \\
(2010-2011)\end{array}$} & \multicolumn{2}{|c|}{ Calibration (2010) } & \multicolumn{2}{|c|}{ Validation (2011) } \\
\hline & Original & Modified & Original & Modified & Original & Modified & Original & Modified & Original & Modified & Original & Modified \\
\hline DQR & 0.7 & 0.82 & 0.73 & 0.83 & 0.65 & 0.76 & 25.59 & 16.67 & 13.6 & 17.48 & 37.36 & 15.07 \\
\hline KKR & 0.64 & 0.78 & 0.67 & 0.82 & 0.62 & 0.75 & -12.06 & -8.79 & -11.22 & -4.05 & 13.62 & 7.94 \\
\hline HZR & 0.71 & 0.77 & 0.76 & 0.85 & 0.68 & 0.72 & 18.55 & -9.95 & 20.95 & -8.13 & 15.3 & -12.43 \\
\hline PSR & 0.74 & 0.86 & 0.75 & 0.88 & 0.75 & 0.82 & 13.68 & 3.56 & 12.4 & 2.06 & 15.23 & 5.38 \\
\hline
\end{tabular}

The results of the model simulation on a daily scale were selected to compare the simulation effects of the mountainous rivers at different latitudes before and after model modification. First of all, the simulation results of the calibration and validation periods of the DQR are shown in Figure 3(a1,a2). In the calibration period (2010), the runoff gradually increased beginning at the end of April, and there were two flood events in early May. However, the first flood event was neglected in the simulation of the original model. The modified model was obviously superior to the original model in the process simulation of the flood events. Although a certain amount of overestimation occurred in the second simulation, overall the results were greatly improved. In June, the original model produced underestimation in the overall runoff simulation, and some of the flood events were neglected. In July, the runoff decreased rapidly, and the simulation results of the original model overestimated and neglected the small flood events. However, the modified model not only simulated the process of runoff reduction well but also showed the smaller flood events in these two months. In terms of the validation rate (2011), there was a large advance in the spring flood time. At the end of March, the runoff began to increase significantly, and snowmelt floods occurred. However, the performance of the original model for this process was not satisfactory. Starting in May, the frequency of the flood events increased significantly. The original model underestimated the results, while the modified model was well simulated.

Unlike the DQR, the snowmelt floods of the KKR mainly began in April. In addition, during the whole snowmelt season, the peak value of the flood was less than $50 \mathrm{~m}^{3} / \mathrm{s}$. The results of the calibration comparison are shown in Figure 3(b1). In the simulation of a snowmelt flood in spring, the original model directly skipped the flood process in this stage, but after the modification, the size of the simulation was more reasonable. When entering the summer, the overall results of the original model were significantly underestimated. The simulation of the multi-flood peak produced by the modified model was more accurate, which made up for the defects of the original model. During the validation period Figure 3(b2), a number of consecutive snowmelt flood events occurred starting in April. Only the individual flood time was performed, and most flood events did not respond well and were usually underestimated. Both the performance of the snowmelt flood in spring and the performance of the summer flood produced by the modified model were closer to the measured value and had excellent performance. 

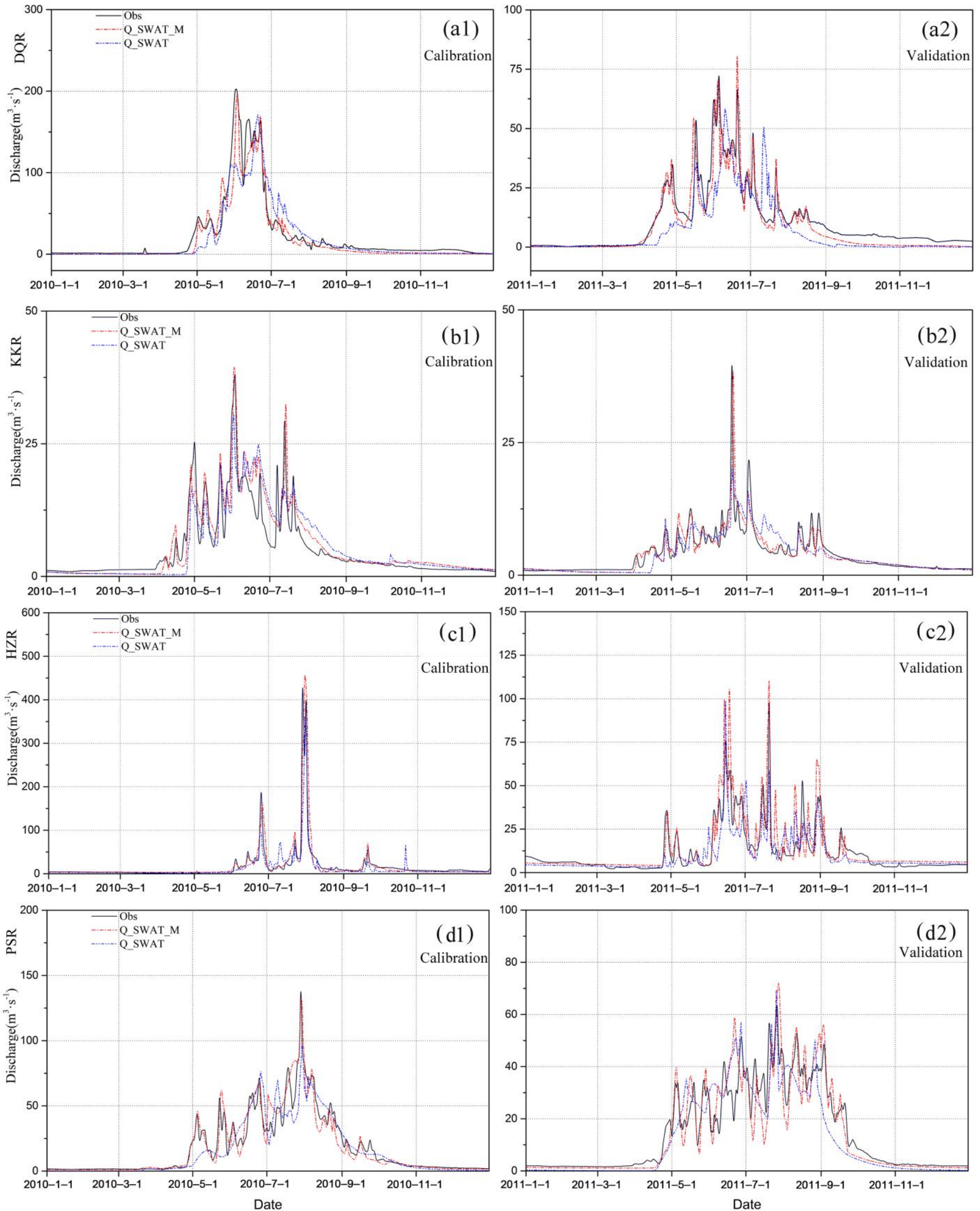

Figure 3. Simulation results of different river basins on a daily scale ((a1-d1) represented the Daqing River Basin (DQR), Kaiken River Basin (KKR), Heizi River Basin (HZR), and Pishan River Basin (PSR) at calibration rate simulation results, and (a2-d2) were the simulation results of the validation periods). 
In the simulation results of the HZR, the snowmelt incident occurred later, and the snowmelt flood at the end of May was identified. During the summer, several smaller flood events occurred, which were not simulated well, while the modified model produced better results, i.e., the simulation results were closer to the measured values. In the simulation of the validation period's Figure 3(c2) spring snowmelt flood events, the modified model had obvious advantages, almost every flood process was simulated well, while the original model produced significant underestimations, and the performance of the flood process was inaccurate. In the summer, the original model underestimated the results overall, while the modified model overestimated the flood process accurately.

The snowmelt event in the PSR also started at the end of April. In the calibration period Figure 3(d1), for the simulation of the two large snowmelt floods in May, the original model simply showed a stable increase in the runoff. After modification, the flood process was well represented. Similar to other river basins, in the summer flood event simulation process, the results of the original model were underestimated, and the flood peak was not simulated well, and the modified model significantly improved the results. During the validation period Figure 3(d2), the modified model performed well and improved on the original model's shortcomings. The original model did not accurately represent the time and size of the flood process. In addition, the flood events in September could not be performed, and the modified model simulation's accuracy was improved.

\subsection{Characteristics of Flood Process}

In this section, the characteristic factors of the flood processes in the different basins were analyzed, such as the peak discharge, the peak deviation, and the contribution rate to the river channel. Statistical analysis of the flood peak deviation of each flood event was also very important when verifying the effect of the model modification and comparing and analyzing the snow melting flood characteristics of the different altitudes. The method adopted was to treat all of the flood events in the calibration and validation periods as the research object. The peak deviation of the flood was represented by the difference between the measured and the simulated values. The deviation of each flood peak was counted. As can be seen in Figure 4a, there were a total of 16 flood events in the DQR during 2010 and 2011, and the flood peak deviations of the simulation results before and after the model modification were analyzed. For the simulation results of the original model, the maximum flood peak deviation was $92.20 \mathrm{~m}^{3} / \mathrm{s}$, and the average flood peak deviation was $32.76 \mathrm{~m}^{3} / \mathrm{s}$. For the simulation results of the modified model, the maximum flood peak deviation was $39.5 \mathrm{~m}^{3} / \mathrm{s}$, and the average flood peak deviation was $8.55 \mathrm{~m}^{3} / \mathrm{s}$. Through modification of the model, the deviation of each flood peak was improved, and the accuracy of the flood peak deviation in the DQR was increased by $72.98 \%$. In Figure $4 \mathrm{~b}$, based on the flood peak deviation statistics of 25 flood events in the KKR, the maximum peak deviation occurred in the simulation results of the original model of the validation period in June, with a maximum of $31.14 \mathrm{~m}^{3} / \mathrm{s}$, and the average peak value deviation was $6.93 \mathrm{~m}^{3} / \mathrm{s}$. By comparing the simulation results of the models, it was found that the maximum peak deviation of the modified model was $31.17 \mathrm{~m}^{3} / \mathrm{s}$, the minimum value was only $0.07 \mathrm{~m}^{3} / \mathrm{s}$, and the average deviation was $4.78 \mathrm{~m}^{3} / \mathrm{s}$. Compared with the simulation results of the original model, the accuracy was improved by 31\%. There were 17 flood events in the HZR during the calibration and validation periods (Figure 4c). The overall flood peak deviation was larger, and the maximum value was up to $399.46 \mathrm{~m}^{3} / \mathrm{s}$. However, after the modification of the model, the flood peak deviation of this flood event was reduced to $276.16 \mathrm{~m}^{3} / \mathrm{s}$, which was an improvement of $30.87 \%$. The average deviation of the original model was $66.14 \mathrm{~m}^{3} / \mathrm{s}$. After the modification, the average deviation of all of the flood peaks was increased to $31.70 \mathrm{~m}^{3} / \mathrm{s}$, and the accuracy was increased by $52.07 \%$, which made the simulation of the flood events closer to the measured values. 

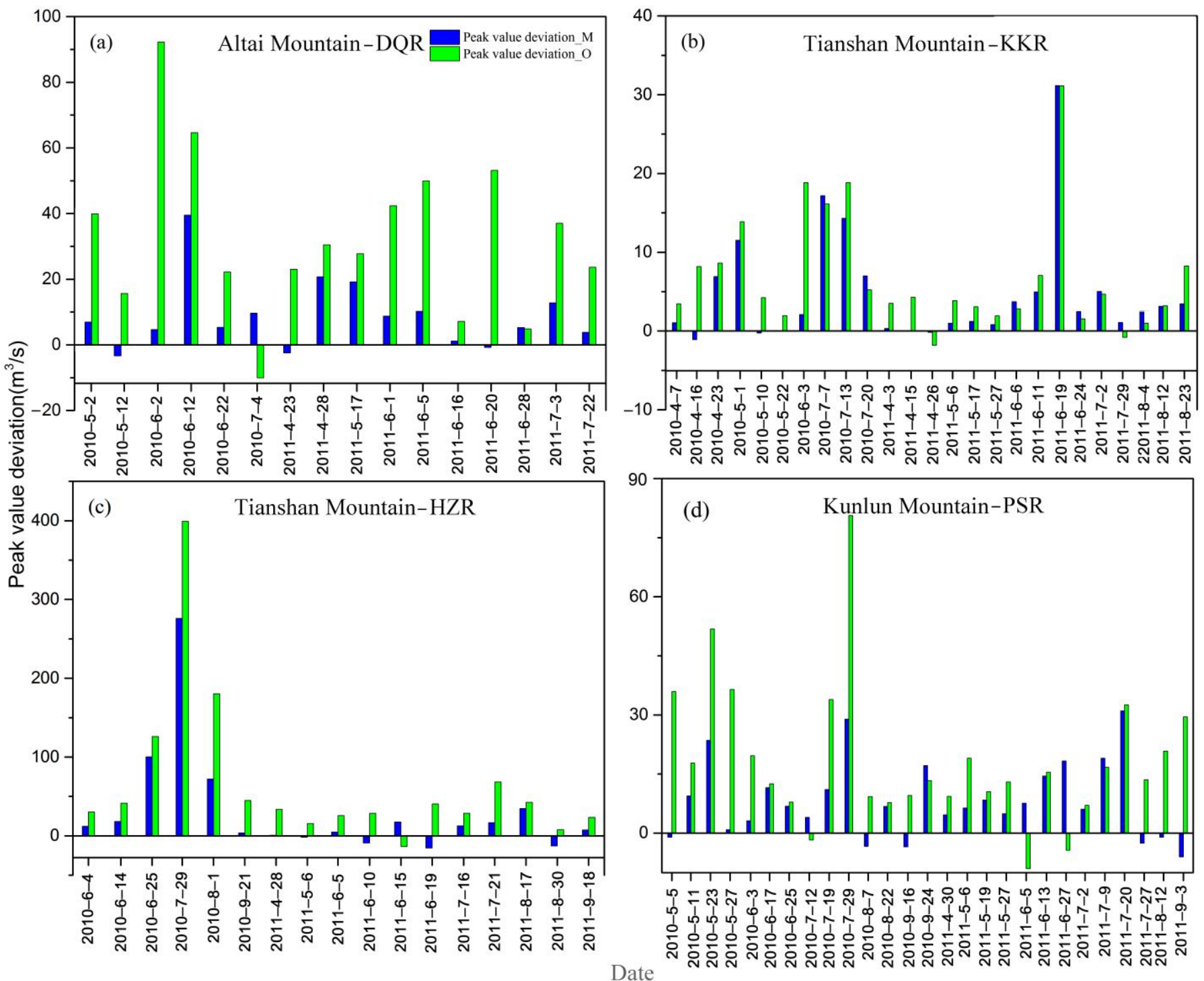

Figure 4. Comparison of flood peak deviations in different basins (a), DQR in Altai Mountain; (b), KKR in Tianshan Mountain; (c), HZR in Tianshan Mountain; (d), PSR in Kunlun Mountain).

Among the four rivers, the PSR had the most flood events (Figure 4d), up to 27, and the maximum deviation of the peak flood $\left(80.64 \mathrm{~m}^{3} / \mathrm{s}\right)$ occurred in summer. In the modified model simulation results, the deviation decreased to $28.95 \mathrm{~m}^{3} / \mathrm{s}$, which was a significant improvement. In the original model, the average deviation of the flood peak value was $18.86 \mathrm{~m}^{3} / \mathrm{s}$. Through the modification of the model, the average deviation was decreased to $8.39 \mathrm{~m}^{3} / \mathrm{s}$ (by $55.49 \%$ ). By comparing the flood peak deviation of the four rivers, it was obvious that the overall flood peak deviation of the modified model was significantly improved, especially during the period of high snowmelt flooding in spring.

\subsection{The Relationship between Snowmelt and NDVI in Spring}

In high-altitude mountainous areas, the snow melting and ice melting in the arid and semi-arid areas were of great significance to the local ecology and production, including the green vegetation in spring [51]. Snow melting and ice melting directly affect the vegetation growth. NDVI extracted and calculated from MODIS can reflect the growth of vegetation in spring [52,53]. Therefore, the correlation between vegetation NDVI and the amount of melting water can indirectly verify the effect of the model modification and the accuracy of the calculation from an ecological perspective, which can also prove the practicability 
of the model in different basins before and after modification. In arid and semi-arid highaltitude mountainous areas, vegetation types were mainly alpine meadow with sparse canopies [54-57]. Compared with Leaf Area Index (LAI), NDVI is more accurate and more suitable for reflecting vegetation growth and verifying the accuracy of model calculation in this area. In this study, the distribution of the NDVI values in spring in the four watersheds and the relationship between the NDVI values and the snowmelt calculated using the models were analyzed.

In high altitude mountainous areas, there is less precipitation in spring, and snowmelt provides a large amount of the water required for vegetation growth. Therefore, snow melt can be used as an important influencing factor in the evaluation and analysis of vegetation growth. In order to better determine the relationship between the amount of snowmelt and the NDVI, the average NDVI value per 8 days in the spring watershed was obtained and compared with the corresponding amount of snowmelt (Figure 5). In the DQR, which has the highest latitude, the amount of snowmelt calculated by the original model was compared with the NDVI. The correlation between the two was not significant, and the correlation coefficient was only 0.16 . After the modification of the original model using the degree day factor method, the correlation between the snowmelt calculated by the new model and the NDVI was increased to 0.75 , revealing a high correlation. For the original model simulation results of the KKR, the correlation between the amount of snowmelt and the NDVI was 0.25 , which reveals a low correlation. Compared with the NDVI, the amount of snowmelt calculated using the modified model had a correlation coefficient of 0.63 . In the HZR, on the southern slope of the Tianshan Mountains, the correlation coefficient calculated by the original model was 0.31 , while that of the modified model was 0.71 , indicating a better correlation. In the PSR, in the Kunlun Mountains, the correlation between the amount of snowmelt of the original model and NDVI was only 0.37 , while that of the modified model reached 0.64 . Therefore, for the mountain systems at these three different altitudes, the correlation between the amount of snowmelt and the NDVI was significantly improved by the model modification, which demonstrates the necessity and accuracy of the model modification.
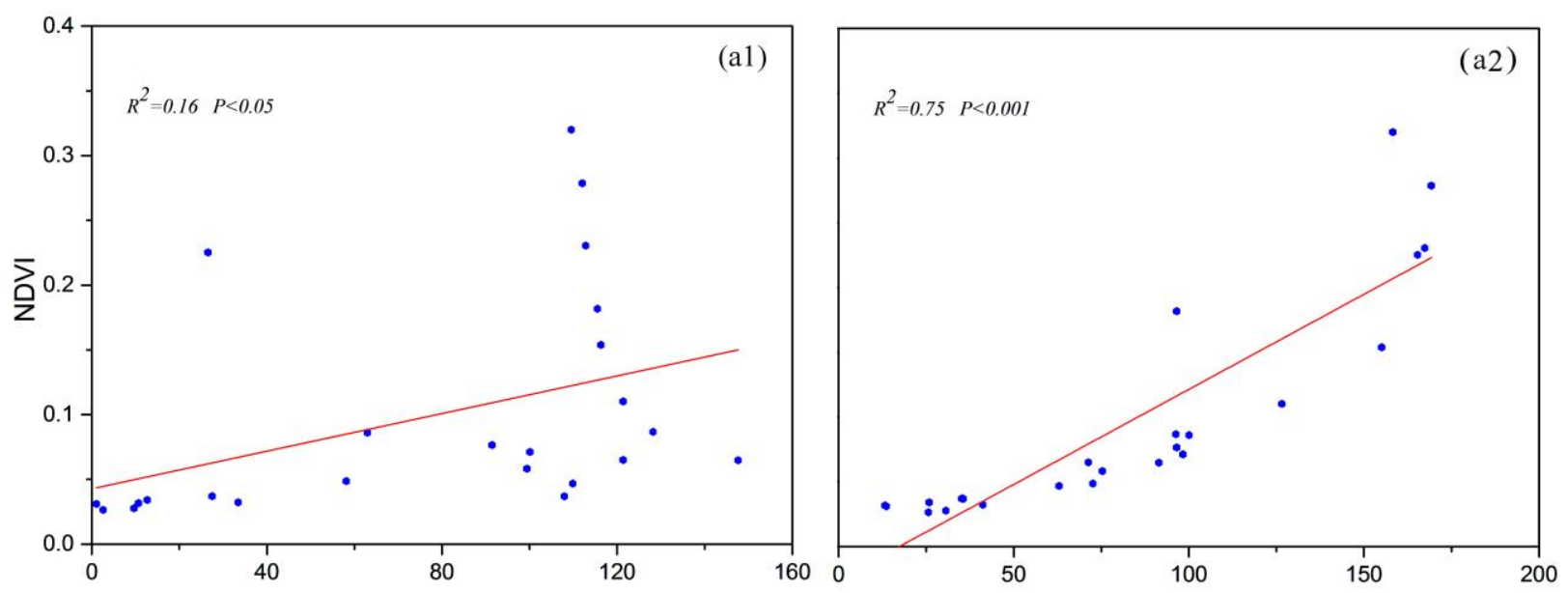

Figure 5. Cont. 

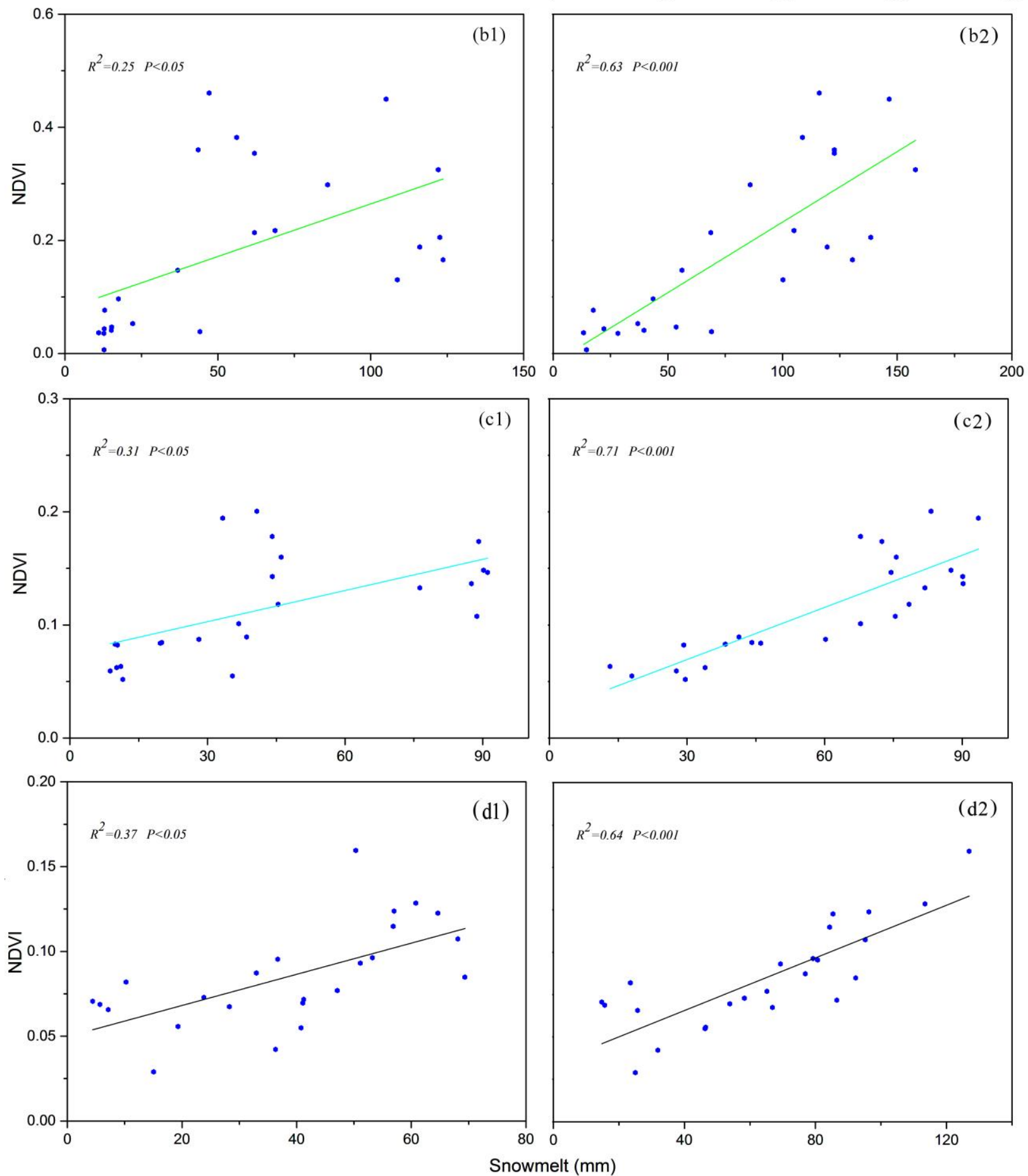

Figure 5. Comparison of the relationship between snowmelt amount and Normalized Difference Vegetation Index (NDVI) calculated before and after the model modification in spring ((a1-d1) Relationship between snowmelt volume calculated by the original model and NDVI of DQR, KKR, HZR, and PSR in Spring; (a2-d2), relationship between snowmelt volume calculated by the modified model and NDVI of DQR, KKR, HZR, and PSR in Spring).

The distributions of the NDVIs of each basin from March to May in spring were compared and analyzed in Figure 6. In the DQR, the vegetation regeneration in March was mainly concentrated in a small area in the middle of the basin. In April, the vegetation gradually began to regenerate in the middle and lower reaches of the basin. By May, both sides of the river and most of the middle and lower reaches of the river were basically covered by regenerated vegetation. In March, the vegetation in the KKR was 
mainly distributed in the catchment area upstream of the basin. In April, the vegetation regeneration accelerated and the vegetation area increased in some of the downstream areas. The vegetation in the lower reaches of the basin increased in May, and the vegetation area expanded. The same situation occurred in the upstream watershed. In the HZR, the vegetation distribution in March and April was mainly in the upper reaches of the basin, but in May, the vegetation returned, the vegetation area in the upper reaches of the basin expanded, the vegetation distribution also appeared in the middle reaches of the river convergence, and the new vegetation appeared in the downstream outlet area. Compared with the other three basins, the vegetation regeneration time in the PSR obviously lagged behind. The Pishan River, located in Kunlun Mountains, with least precipitation among the four basins and was a typical representative of the rivers in the arid region. There was less rainfall in spring and the water needed for vegetation greening was mainly from melting snow in high altitude mountain areas [22,58,59]. The altitude was so high and meteorological conditions were so complicated that the temperature began to rise, the snow began to melt, and the river runoff increased until in April $[60,61]$. The vegetation regeneration was started when water source was plentiful. Due to the altitude and complex meteorological conditions, vegetation regeneration in Pishan River Basin was late and obviously lagged behind [62]. The time of snow melt in each basin can be accurately located by studying the time of vegetation regeneration in each basin. As the main water supply, the amount of snow melt affects the vegetation regeneration and growth, and there is a significant relationship between them. Therefore, the accuracy and rationality of the model modification can be verified by establishing the correlation between NDVI and snow melt. The NDVI data for May showed that the vegetation area had significantly expanded, the vegetation regeneration had also accelerated, and there was a significant distribution of vegetation in the upstream and middle reaches of the basin.
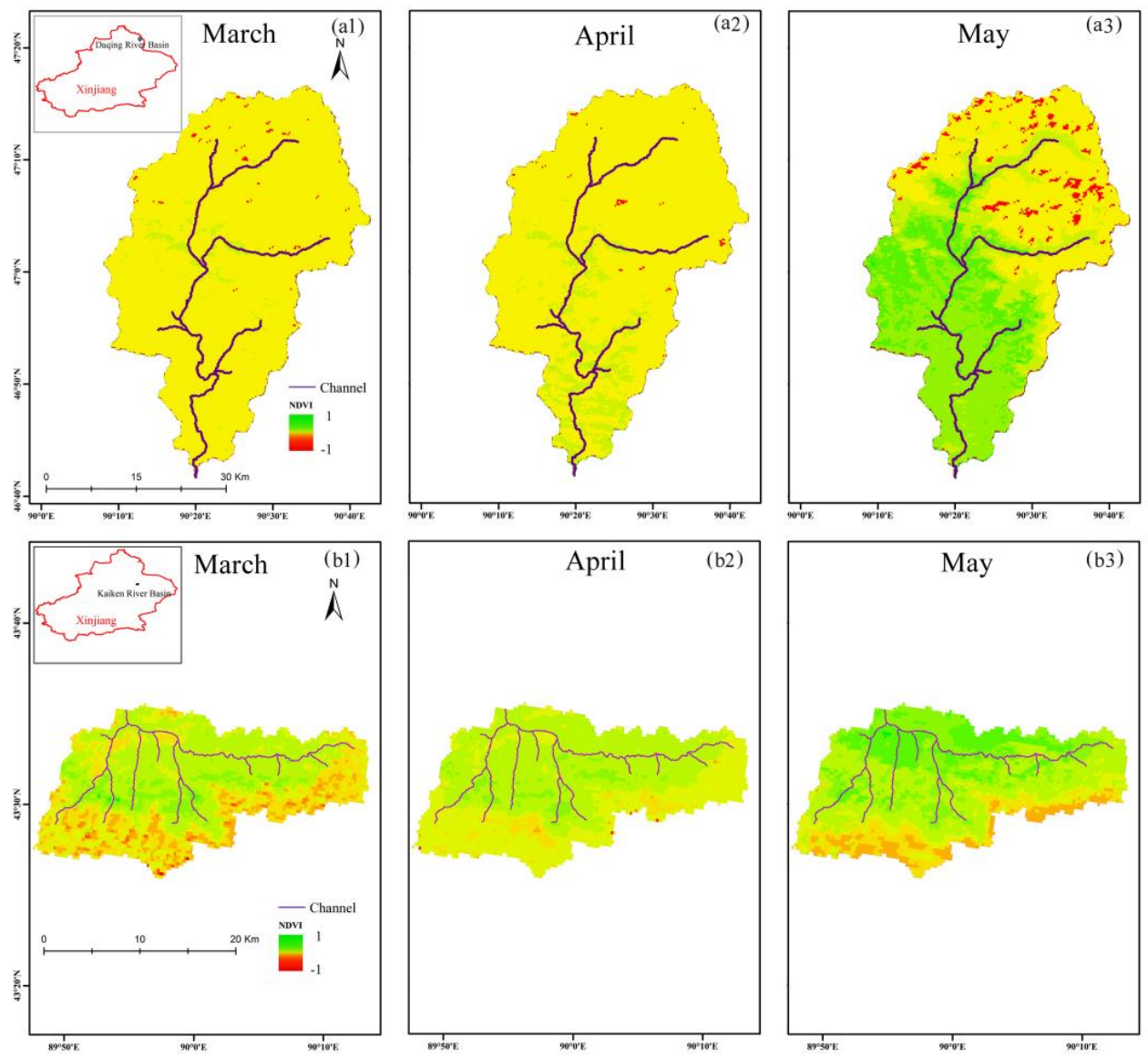

Figure 6. Cont. 

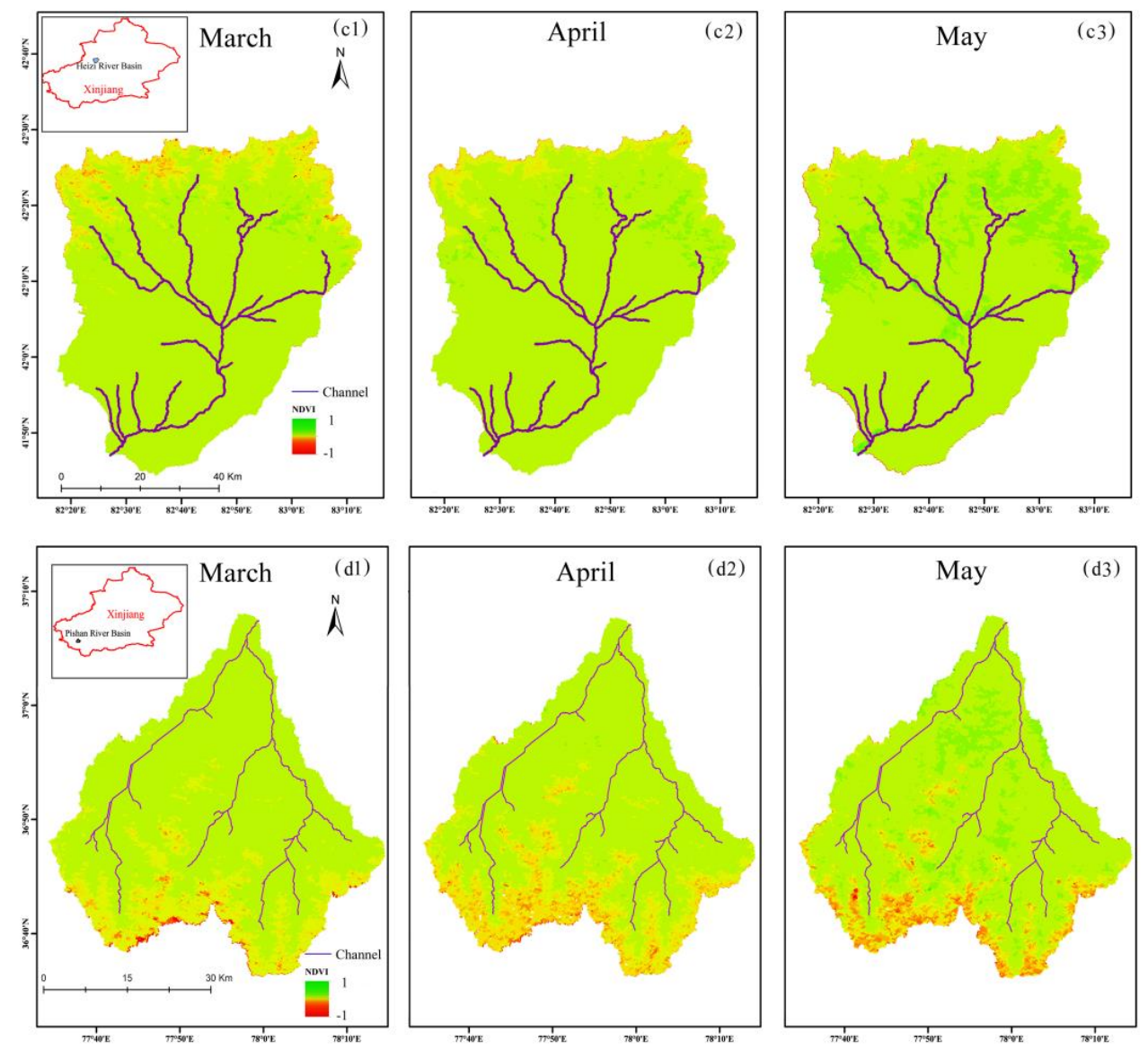

Figure 6. Difference of vegetation growth in different latitude basins reflected by NDVI ((a1-d1), the NDVI of DQR, KKR, HZR, and PSR in March; (a2-d2), the NDVI of DQR, KKR, HZR, and PSR in April; (a3-d3), the NDVI of DQR, KKR, HZR, and PSR in May).

\section{Discussion}

\subsection{The Modification of SWAT Model}

In this study, small- and medium-sized rivers in high-altitude mountainous areas with different dimensions were selected as research objects, which were used to verify the modification effect of the model in different dimensions and different watersheds. In addition, the flood processes of these rivers, which were often neglected in areas lacking data, were investigated $[11,63,64]$. It snows heavily starting in November each year $[14,15,65-68]$, and snow is stored every winter. The climate of the Kunlun Mountains is drier, but in high altitude mountainous areas affected by airflow and topography, there is snowfall at high altitude in winter $[20,58]$. As an important water source, these snow deposits provide irreplaceable water sources for vegetation regeneration and agricultural production. When the spring temperature rises rapidly, the snow in these high areas begins to melt quickly, and the snowmelt flows into the rivers [29,69-71]. Due to the large altitude difference, snow melting floods develop easily [72-74]. Therefore, the accuracy of the snowfall determines the accuracy of the model calculation, which means that determining the precipitation patterns was crucial.

In the original model, the daily average temperature was used as the basis for the morphological discrimination of the precipitation data input $[75,76]$. Considering that the area the original SWAT model was applied to was a plain area, this method of determination is desirable [31,77-79]. In the high-altitude mountainous areas of Xinjiang, the temperature difference during one day can be very large [59]. Due to the sparse surface vegetation and the distribution of the rocky gravel, the temperature at noon rapidly increases and reaches the highest temperature $[80,81]$. At night, the temperature quickly drops below 
zero. For a region with such a large temperature difference, the daily average temperature was used as the precipitation condition for the temperature determination condition, which cannot meet the accuracy requirement [81,82]. Therefore, in this study, the temperature determination condition of the accumulated temperature was added to determine the precipitation pattern.

When calculating the snowmelt, the conditions of the snow melting were determined. The snow melting temperature threshold was set to determine whether there was snow melting. Because of the high temperature at noon and the low temperature at night in high altitude mountain areas, it was difficult to accurately calculate the snow melting conditions using only the maximum daily temperature as the criterion for snow melting [83-85]. By setting a new accumulated temperature threshold, the original model calculation was satisfied, and the special climatic conditions and topographic conditions of the alpine region were fully considered to make up for the shortcomings of the previous high-altitude mountain model.

\subsection{The Performance of the Model}

The performance of the modified model was mainly based on the deviation in the flood peak value. Among the three major mountain systems in Xinjiang, the high-altitude mountainous areas were prone to snowmelt floods in spring. Flood disasters in areas that lack data were often neglected $[15,65]$. By determining the precipitation pattern of the model and the effect of the increasing accumulated temperature on the snow melting process, the performance of the modified model during snowmelt and flood peak was significantly improved. Statistical analysis was performed using the peak deviation of all of the flood events for each river during the study period. For all of the spring flood events in the four basins, the simulation results of the modified model indicate that the deviation in the flood peak value was significantly improved. This was mainly due to the fact that the effect of the accumulated temperature on snow melting was taken into consideration, the snow melting conditions were no longer determined using only the daily average temperature, and the daily maximum temperature and the snow pack temperature were taken into account $[10,28,30]$. By increasing the threshold of the accumulated temperature, the underestimation of snowmelt floods in high altitude mountainous areas can be eliminated to some extent by the original model. In high-altitude mountainous areas, the ground temperature has a direct impact on the melting of snow. This energy accumulation process can reflect the influence of the temperature on the snowmelt $[27,86]$. This method can determine the occurrence of snow melting well when the daily maximum temperature does not reach the threshold of the snow melting temperature [87]. By adding the judgment conditions of the accumulated temperature, the time of the snowmelt can be accurately obtained, which provides a possibility for simulating the flood process with a high time resolution. In the simulations of the individual summer flood events in the KKR and PSR in the validation period, the performance did not reach the expected value. This was mainly due to the following reasons. First, there may be delays in peak floods, but the deviation statistics were only based on the simulated values of the day the data were measured [25]. Due to the cumulative effect of the accumulated temperature, snow melting may also occur at night, which increases the amount of snowmelt the next day and delays the time of the peak flood [88]. Second, it may be the choice of parameter combinations, because the parameter combination selected periodically cannot fully meet the requirements of the validation period calibration. However, in general, the model modification was excellent and achieved the expected goal [89].

The four rivers selected for this study represent the flood characteristics of high altitude mountainous areas in different latitudes in Xinjiang. These areas were mainly investigated using the start time of the snowmelt flood, the frequency of occurrence, and the size of the flood. In the DQR in the Altai Mountains, snowmelt floods usually begin at the end of April and the beginning of May. This is mainly due to the significant increase in temperature and the melting of snow in the Altai area at the end of April [14,90-92]. In the 
KKR on the northern slope of the Tianshan Mountains, snow melting mainly begins at the end of March, and snow melting floods mainly begin at the end of March and the beginning of April [18,93-96]. This was because the latitude of the Kaken River is lower than that of the DQR, so its temperature begins to rise earlier in the spring [67,97]. In the HZR on the southern slope of the Tianshan Mountains, the snow begins to melt in May, while flooding begins in May and June. This was mainly due to the abundant water vapor and precipitation in the high altitude mountainous areas on the southern slope of the Tianshan Mountains [20,98]. Snowfall still occurs in March and April, and the temperature rise lags behind. The PSR is located in the northern part of the Kunlun Mountains. Snow melting floods also begin at the end of April in this region. Because of the sparse vegetation in the Kunlun Mountains, the snow is covered with rock and gravel. In April, the temperature in the basin increases, and the snow rapidly melts, causing a snow-melting flood $[31,99,100]$.

It was not difficult to determine that the frequency of floods in the DQR was the lowest among the four rivers. This was mainly due to the fact that the Altai Mountain has the lowest average elevation of the three mountain systems, the climate changes are relatively stable, and more snow falls than rain. Thus, even in summer, the frequency of mixed flood occurrence was the smallest of these basins. The KKR and PSR located in the Tianshan Mountains experience more frequent floods. In spring, snow melting floods are the main cause, while in summer, there is more rainfall, which makes it easy for rainfall floods and mixed floods to form. On the northern slope of the Kunlun Mountains, where the PSR is located, precipitation is scarce, but there was still a high frequency of flood disasters. This was mainly due to the sparse vegetation on the surface and the large temperature difference between day and night, which was caused by the special surface cover. The snow-melting floods form more easily and were the main type of flood in this basin [58].

In the comparison of the flood peak values of the snow melting floods in spring, the highest average flood peak value (up to $54.76 \mathrm{~m}^{3} / \mathrm{s}$ ) occurred in the DQR in the Altai Mountains. This was because the Altai Mountains have the most snowfall in winter, and most of the precipitation in the year occurs as winter snowfall. A large amount of snow accumulates, the temperature in the spring increases, and the large amount of snow melt forms a snowmelt flood. The minimum value was $19.81 \mathrm{~m}^{3} / \mathrm{s}$ in the KKR on the northern slope of the Tianshan Mountains. This was mainly due to the fact that the basin was located in the eastern part of the Tianshan Mountains and experiences less precipitation [18,80], less snow in the winter, and less snow melting in spring, which made the peak value of the snow melting floods smaller than those of other rivers. Of the summer flood events, the river with the highest average peak value $\left(201 \mathrm{~m}^{3} / \mathrm{s}\right)$ was the Heizi River Basin. This was mainly due to the fact that based on the snow melt, the basin experiences the most rainfall during the summer, which was the most likely the cause of the large mixed floods and rainfall floods. The second was that the PSR had a peak value of $53.52 \mathrm{~m}^{3} / \mathrm{s}$. This was because, even though there was less precipitation in the summer, the abundant permanent snow and glaciers at high altitudes melt as the temperature increases, which caused flood events $[83,101,102]$. The minimum peak of the summer flooding $\left(31.38 \mathrm{~m}^{3} / \mathrm{s}\right)$ still occurred in the KKR.

In September, snowfall gradually increased in high altitude mountainous areas, but the temperature was not stable, and the temperature difference between day and night was very large $[103,104]$. The daily average temperature was only used to determine the conditions of snowmelt in the original model. At high altitude mountain areas, ground vegetation was scarce, mainly composed of rocks and sand, when the temperature rise at noon, the snowpack began to melt and supply channel flow received the influence of the accumulated temperature $[14,105,106]$. When daily average temperature was lower but not the accumulated temperature, there were still a month of snowmelt replenishing river runoff [107]. This can lead to an underestimate of river runoff over a period of time, such as in September and October. 


\subsection{Effect of Snowmelt on Vegetation Growth}

In order to study the relationship between the amount of snow melt and vegetation growth, the difference in vegetation growth at different latitudes in Xinjiang was analyzed. In the DQR in the Altai Mountains, vegetation rejuvenation begins in March, increases in April, and increases rapidly in May. Similar to the DQR, the KKR, which is located in the eastern section of the Tianshan Mountains, also begins rejuvenation in March, with an increase in April. By May, the vegetation has grown very well. However, the HZR in the southern foothills of the Tianshan Mountains was not significant in March, and there was only a small increase in April. In May, the vegetation growth was slower than that in the DQR and the KR. The PSR in the Kunlun Mountains only begins to grow vegetation in May. This difference was mainly considered to be the result of two aspects. First, the altitude of the DQR and KKR was significantly lower than that of the HZR and PSR. When spring comes, the melting snow at low altitudes melts quickly, which had an important impact on vegetation rejuvenation and growth $[17,62,68,108-110]$. The second was precipitation. The average annual precipitation in the DQR and the KKR was significantly higher than that in the HZR and the PSR, which means that there is a great deal of snowfall and snow pack in the winter, creating a larger water reserve and providing sufficient water for vegetation rejuvenation $[22,24,111,112]$.

As an important water source for vegetation growth and farming in the spring, snow cover plays an irreplaceable role in the local ecosystem. Based on the NDVI values of the four basins (Figure 3), the process of spring vegetation rejuvenation can be clearly seen. By May, the area of green vegetation had expanded significantly [22,111,112]. This was because, in high altitude mountainous areas, as the temperature increases, the snow began to melt and the soil moisture was recharged, providing a water source for the greening and growth of vegetation $[24,62,110]$. The snowmelt quickly entered the river and the river runoff increased. In the lower reaches of the river basin, there was a large area of arable land. The river water was diverted by the farmers to irrigate these crops, which increased the vegetation area and accelerated the growth in May. Therefore, the relationship between the NDVI of the spring vegetation and the amount of snow melt was closely related. It was necessary to study the correlation between these two factors [22,24]. The relationship between the amount of snowmelt and the NDVI calculated using the original model was investigated in the PSR. $\mathrm{R}^{2}$ was only 0.37 , showing a lower correlation. However, the amount of snowmelt calculated using the modified model had a high correlation with the NDVI, which was consistent with the actual situation, fully affirming the necessity of model modification.

\subsection{The Sensitivity and Uncertainty Analysis}

In the process of model simulation, parameter calibration is indispensable. It is mainly used to determine the parameter values used in model calculation [113]. The optimal combination of parameters was determined through hundreds of runs [47,114]. In the study of the model modification, two parameters were added to determine the precipitation pattern and the accumulated temperature of the snowmelt, i.e., the daily accumulated temperature threshold of rainfall (SFTMP_A) and the daily accumulated temperature threshold of snowmelt (SMTMP_A). The values of these two parameters in different watersheds were determined through calibration shown in Table 4. In the DQR, the value of parameter SFTMP_A was $24.24{ }^{\circ} \mathrm{C}$, and the value of parameter SMTMP_A was $18.35^{\circ} \mathrm{C}$. In addition, the sensitivity of the parameters was confirmed. The T-state value of parameter SFTMP_A was 3.34, and the $p$-value was 0.06 , while the T-state value of parameter SMTMP_A was 8.34, and the $p$-value was 0.01 , which indicated a strong sensitivity. In the KKR, the determined values of SFTMP_A and SMTMP_A were $22.09^{\circ} \mathrm{C}$ and $19.46^{\circ} \mathrm{C}$, respectively. In the performance of the sensitivity analysis, the T-state of parameter SFTMP_A was 4.05, and the $p$-value was 0.08 , while the T-state of parameter SMTMP_A was 8.86, and the $p$-value was 0.01. In the HZR, the value of SFTMP_A was $20.18^{\circ} \mathrm{C}$, and the value of parameter SMTMP_A was $17.5^{\circ} \mathrm{C}$. In the sensitivity analysis, the 
T-state of parameter SFTMP_A was 5.27, and the $p$-value was 0.04 . The T-state of parameter SMTMP_A was 9.05, and the $p$-value was 0.01 . In the PSR, the value of parameter SFTMP_A was $25.62{ }^{\circ} \mathrm{C}$, and that of parameter SMTMP_A was $20.18{ }^{\circ} \mathrm{C}$. The T-state and $p$-value of parameter SFTMP_A were 3.28 and 0.07 , respectively; while those of parameter SMTMP_A were 7.55 and 0.02 , respectively. The two new parameters showed strong sensitivity in the four watersheds, indicating that the snow melting process was an important part of the watershed, which reflected the rationality and importance of the new parameters.

Table 4. Parameter SFTMP_A and SMTMP_A information for global sensitivity.

\begin{tabular}{ccccccc}
\hline \multicolumn{3}{c}{ SFTMP_A } & \multicolumn{3}{c}{ SMTMP_A } \\
\hline Basins & $\begin{array}{c}\text { Calibration } \\
\text { Value }\left({ }^{\circ} \mathbf{C}\right)\end{array}$ & T-States & $p$-Value & $\begin{array}{l}\text { Calibration } \\
\text { Value }\left({ }^{\circ} \mathbf{C}\right)\end{array}$ & T-States & $p$-Value \\
\hline DQR & 24.24 & 3.34 & 0.06 & 18.35 & 8.34 & 0.01 \\
KKR & 22.09 & 4.05 & 0.08 & 19.46 & 8.86 & 0.01 \\
HZR & 20.18 & 5.27 & 0.04 & 17.5 & 9.05 & 0.01 \\
PSR & 25.62 & 3.28 & 0.07 & 20.18 & 7.55 & 0.02 \\
\hline
\end{tabular}

The uncertainty analysis of the model simulation results was also an important part of the model-related research $[48,89,115]$. In this study, the uncertainty analysis was discussed from three aspects: The model structure algorithm, the data source, and the parameters $[48,116,117]$. The structure and algorithms of each model introduced uncertainties, especially when applied to different study areas. The fact that the watersheds selected in this study are located in high-altitude mountainous areas that lack data added a significant amount of uncertainty. The different parameter values, different parameter combinations, and different thresholds brought corresponding uncertainties $[49,118]$. As a conventional algorithm to calculate daily accumulated temperature, there was also some uncertainty. The change of daily temperature was considered to be relatively smooth, and abrupt changes in temperature did not take into account. In this way, there were some uncertainty in the daily accumulated temperature calculation, which is also one of the key points to be improved in future work. The influence of climate change on vegetation NDVI in Xinjiang has been studied by some scholars. The study shows that the climate in much of Xinjiang experienced warming and wetting trends, and rainfall increased in mountainous areas in summer $[23,119,120]$. Through field investigation, it was also found that in the mountainous area of arid area, especially in the Kunlun Mountains, rainfall increased in summer and vegetation area increased obviously. NDVI was introduced in this paper as the verification of model modification. Therefore, in order to more accurately reflect the relationship between vegetation growth and snow melt, the vegetation NDVI in Spring was selected as the focus, which effectively excluded the influence of summer rainfall and climate change. The relationship between vegetation NDVI and snow melt calculated by the model can accurately reflect the accuracy of the model.

\section{Conclusions}

In this study, the original SWAT model was modified to determine the precipitation pattern and the temperature conditions of the snow melting conditions, and the threshold of the accumulated temperature was added to the model. In order to verify the applicability of the modified model, it was applied to the small and medium rivers in three mountain systems at different latitudes in Xinjiang, and the simulation results were compared and verified. By modifying the model, the NS coefficient of the four rivers in the overall study period increased by $14.29 \%$, and the PBIAS increased by $44.25 \%$ on average.

As a direct result of the model modification, the amount of snowmelt can directly reflect the necessity of the snowmelt module modification. Through this modification, the calculated amount of snowmelt in the DQR increased by $12.67 \%$, and the calculated contribution rate of the snowmelt to the channel increased by $25.31 \%$. In the KKR, the calculated amount of snowmelt in the spring increased by $37.05 \%$, and the calculated 
contribution of the snowmelt to the channel increased by $18.65 \%$. In the HZR, the calculated amount of snowmelt increased by $43.38 \%$, the calculated contribution rate increased by $28.29 \%$, the calculated snowmelt volume of the PSR increased by $70.12 \%$, and the calculated recharge of the river channel increased by $35.84 \%$.

Through the modification of the model, the deviation in the flood peak value in the DQR was decreased by $71.56 \%$, the precision of the results for the KKR was improved by $31.00 \%$, the deviation of the flood peak value in the HZR was decreased by $52.07 \%$, and the deviation of the peak value in the PSR was decreased by $70.12 \%$. The results of the modified model are closer to the measured flood peak values.

Combined with the relationship between the amount of snowmelt and the NDVI, it was found that the vegetation in the northern part of the Tianshan Mountains and the high-altitude mountain areas of the Altai Mountains rejuvenates earlier than that in the southern part of the Tianshan Mountains and the Kunlun Mountains, and the vegetation growth in the spring was also more significant. It was mainly caused by the elevation of the basin and the amount of precipitation in winter. In the low-altitude areas, there was more snowfall and snowpack in the winter. In the coming spring, the snow melts earlier, and the snowmelt provides sufficient water for the rejuvenation of vegetation.

Therefore, the modified model had a higher accuracy in the calculation of snowmelt, the recharge of the river, the performance of the flood peak value, and the relationship with the ecosystem. This study provides a new method for accurately investigating snow melting process, hydrological process, and ecological-related research in small and mediumsized rivers in high-altitude mountainous areas, which provides a technical basis for the prevention and control of flood disasters in mountainous areas and also provides new insights into the effects of snowmelt runoff on vegetation growth at different latitudes.

Author Contributions: Conceptualization, Y.D. and M.L.; methodology, Y.D.; software, Y.D. and P.C.; validation, Y.D.; formal analysis, Y.D. and F.L.; investigation, Y.D. and F.L.; resources, M.L.; data curation, Y.D. and P.C.; writing-Y.D.; writing—review and editing, Y.D. and M.L.; visualization, Y.D. and P.C.; project administration, M.L. and X.G. All authors have read and agreed to the published version of the manuscript.

Funding: This research was funded by Natural Science Foundation of Inner Mongolia, grant number: 2020BS03042; 3D numerical simulation study on the influence of lightning rod corona Discharge on lightning strike process, grant number: BK20190147; 3D numerical simulation of the influence of corona discharge on lightning stroke process of tall buildings, grant number: 19KJB170025.

Institutional Review Board Statement: Not applicable.

Informed Consent Statement: Not applicable.

Data Availability Statement: No new data were created or analyzed in this study. Data sharing is not applicable to this article.

Acknowledgments: The authors would like to express their gratitude to the China Meteorological Data Sharing Service System and Xinjiang Tarim River Basin Management Bureau for providing the climate and river flow data, respectively. We are very appreciative of the Key Laboratory of Remote Sensing and Geographic Information System, Xinjiang Institute of Ecology and Geography for providing the LUCC data and the Food and Agriculture Organization (FAO) for providing the soil map.

Conflicts of Interest: The authors declare no conflict of interest.

\section{References}

1. Fierz, C.; Riber, P.; Adams, E.; Curran, A.; Föhn, P.; Lehning, M.; Pluss, C. Evaluation of snow-surface energy balance models in alpine terrain. J. Hydrol. 2003, 282, 76-94. [CrossRef]

2. Jost, G.; Moore, R.D.; Smith, R.; Gluns, D.R. Distributed temperature-index snowmelt modelling for forested catchments. J. Hydrol. 2012, 420, 87-101. [CrossRef]

3. Horton, P.; Schaefli, B.; Mezghani, A.; Hingray, B.; Musy, A. Assessment of climate-change impacts on alpine discharge regimes with climate model uncertainty. Hydrol. Process. 2006, 20, 2091-2109. [CrossRef] 
4. McBean, E.; Motiee, H. Assessment of impact of climate change on water resources: A long term analysis of the Great Lakes of North America. Hydrol. Earth Syst. Sci. 2008, 12, 239-255. [CrossRef]

5. Kriegel, D.; Mayer, C.; Hagg, W.; Vorogushyn, S.; Duethmann, D.; Gafurov, A.; Farinotti, D. Changes in glacierisation, climate and runoff in the second half of the 20th century in the Naryn basin, Central Asia. Glob. Planet. Chang. 2013, 110, 51-61. [CrossRef]

6. Khadka, D.; Babel, M.S.; Shrestha, S.; Tripathi, N.K. Climate change impact on glacier and snow melt and runoff in Tamakoshi basin in the Hindu Kush Himalayan (HKH) region. J. Hydrol. 2014, 511, 49-60. [CrossRef]

7. Xu, M.X.; Yan, M.; Kang, J.C.; Ren, J.W. Comparative studies of glacier mass balance and their climatic implications in Svalbard, Northern Scandinavia, and Southern Norway. Environ. Earth Sci. 2012, 67, 1407-1414. [CrossRef]

8. Fischer, A. Glaciers and climate change: Interpretation of 50 years of direct mass balance of Hintereisferner. Glob. Planet. Chang. 2010, 71, 13-26. [CrossRef]

9. Kim, S.B.; Shin, H.J.; Park, M.; Kim, S.J. Assessment of future climate change impacts on snowmelt and stream water quality for a mountainous high-elevation watershed using SWAT. Paddy Water Environ. 2015, 13, 557-569. [CrossRef]

10. Zhao, Q.-D.; Liu, Z.; Qin, R.; She, Y.-J.; Fang, S.-F.; Lu, Z. Research advance of snowmelt model. Xinjiang Agric. Sci. 2007, 44, 734-739.

11. Wortmann, M.; Krysanova, V.; Kundzewicz, Z.W.; Su, B.; Li, X. Assessing the influence of the Merzbacher Lake outburst floods on discharge using the hydrological model SWIM in the Aksu headwaters, Kyrgyzstan/NW China. Hydrol. Process. 2014, 28, 6337-6350. [CrossRef]

12. Vafakhah, M.; Nouri, A.; Alavipanah, S.K. Snowmelt-runoff estimation using radiation SRM model in Taleghan watershed. Environ. Earth Sci. 2015, 73, 993-1003. [CrossRef]

13. Wolfe, M.L.; Richard, T.L. 21st century engineering for on-farm food-energy-water systems. Curr. Opin. Chem. Eng. 2017, 18, 69-76. [CrossRef]

14. Zhang, Y.; Kang, S.; Gao, T.; Schmale, J.; Liu, Y.; Zhang, W.; Guo, J.; Du, W.; Hu, Z.; Cui, X. Dissolved organic carbon in snow cover of the Chinese Altai Mountains, Central Asia: Concentrations, sources and light-absorption properties. Sci. Total Environ. 2019, 647, 1385-1397. [CrossRef] [PubMed]

15. Wang, P.; Li, Z.; Luo, S.; Bai, J.; Huai, B.; Wang, F.; Li, H.; Wang, W.; Wang, L. Five decades of changes in the glaciers on the Friendship Peak in the Altai Mountains, China: Changes in area and ice surface elevation. Cold Reg. Sci. Technol. 2015, 116, 24-31. [CrossRef]

16. Yin, Z.; Feng, Q.; Zou, S.; Yang, L. Assessing variation in water balance components in mountainous inland river basin experiencing climate change. Water 2016, 8, 472. [CrossRef]

17. Wang, Y.-J.; Meng, X.-Y.; Liu, Z.-H. Snowmelt Runoff Analysis under Generated Climate Change Scenarios for the Juntanghu River Basin, in Xinjiang, China. Tecnol. Cienc. Agua 2016, 7, 41-54.

18. Wang, P.; Mu, Z. Study on relationship of snowmelt runoff with snow area and temperature in KM River Basin. J. Water Resour. 2013, 24, 28-31.

19. Chen, Y.N.; Takeuchi, K.; Xu, C.C.; Chen, Y.P.; Xu, Z.X. Regional climate change and its effects on river runoff in the Tarim Basin, China. Hydrol. Process. 2006, 20, 2207-2216. [CrossRef]

20. Fan, Y.; Chen, Y.; Li, X.; Li, W.; Li, Q. Characteristics of water isotopes and ice-snowmelt quantification in the Tizinafu River, north Kunlun Mountains, Central Asia. Quat. Int. 2015, 380, 116-122. [CrossRef]

21. Sun, G.; Pan, C.; Jiang, L.; Yang, Y. Spatial distribution of the extreme hydrological events in Xinjiang, north-west of China. Nat. Hazards 2013, 67, 483-495. [CrossRef]

22. Gamon, J.A.; Huemmrich, K.F.; Stone, R.S.; Tweedie, C.E. Spatial and Temporal Variation in Primary Productivity (NDVI) of Coastal Alaskan Tundra: Decreased Vegetation Growth Following Earlier Snowmelt. Remote Sens. Environ. 2013, 129, 144-153. [CrossRef]

23. Zhang, F.; Wang, C.; Wang, Z.-H. Response of Natural Vegetation to Climate in Dryland Ecosystems: A Comparative Study between Xinjiang and Arizona. Remote Sens. 2020, 12, 3567. [CrossRef]

24. Mu, Z.-X.; Jiang, H.-F.; Liu, F. Spatial and temporal variations of snow cover area and NDVI in the West of Tianshan Mountains. J. Glaciol. Geocryol. 2010, 32, 875-882.

25. Debele, B.; Srinivasan, R.; Gosain, A.K. Comparison of Process-Based and Temperature-Index Snowmelt Modeling in SWAT. Water Resour. Manag. 2010, 24, 1065-1088. [CrossRef]

26. Wenwu, Q.; Chen, R.; Liu, S.; Han, H.; Jian, W. Research and Application of Two Kinds of Temperature-index Model on the Koxkar Glacier. Adv. Earth Sci. 2011, 26, 409-416.

27. Tuteja, N.K.; Cunnane, C. Modelling coupled transport of mass and energy into the snowpack-Model development, validation and sensitivity analysis. J. Hydrol. 1997, 195, 232-255. [CrossRef]

28. Fernández, A. An energy balance model of seasonal snow evolution. Phys. Chem. Earth 1998, 23, 661-666. [CrossRef]

29. He, X.; Du, J.; Ji, Y.; Zhang, N.; Li, Z.; Wang, S.; Theakstone, W.H. Characteristics of DDF at Baishui Glacier No. 1 region in Yulong Snow Mountain. J. Earth Sci. 2010, 21, 148-156. [CrossRef]

30. Herrero, J.; Polo, M.; Moñino, A.; Losada, M. An energy balance snowmelt model in a Mediterranean site. J. Hydrol. 2009, 371, 98-107. [CrossRef]

31. Fontaine, T.A.; Cruickshank, T.S.; Arnold, J.G.; Hotchkiss, R.H. Development of a snowfall-snowmelt routine for mountainous terrain for the soil water assessment tool (SWAT). J. Hydrol. 2002, 262, 209-223. [CrossRef] 
32. Rahman, K.; Maringanti, C.; Beniston, M.; Widmer, F.; Abbaspour, K.; Lehmann, A. Streamflow Modeling in a Highly Managed Mountainous Glacier Watershed Using SWAT: The Upper Rhone River Watershed Case in Switzerland. Water Resour. Manag. 2012, 27, 323-339. [CrossRef]

33. Omani, N.; Srinivasan, R.; Smith, P.K.; Karthikeyan, R. Glacier mass balance simulation using SWAT distributed snow algorithm. Hydrol. Sci. J. 2016, 62, 546-560. [CrossRef]

34. Pradhanang, S.M.; Anandhi, A.; Mukundan, R.; Zion, M.S.; Pierson, D.C.; Schneiderman, E.M.; Matonse, A.; Frei, A. Application of SWAT model to assess snowpack development and streamflow in the Cannonsville watershed, New York, USA. Hydrol. Process. 2011, 25, 3268-3277. [CrossRef]

35. Schneiderman, E.M.; Matonse, A.H.; Zion, M.S.; Lounsbury, D.G.; Mukundan, R.; Pradhanang, S.M.; Pierson, D.C. Comparison of approaches for snowpack estimation in New York City watersheds. Hydrobiol. Process. 2014, 27, 3050-3060. [CrossRef]

36. Hunt, R.J.; Westenbroek, S.M.; Walker, J.F.; Selbig, W.R.; Regan, R.S.; Leaf, A.T.; Saad, D.A. Simulation of Climate Change Effects on Streamflow, Groundwater, and Stream Temperature Using GSFLOW and SNTEMP in the Black Earth Creek Watershed, Wisconsin; US Geological Survey: Middleton, WI, USA, 2016; pp. 1-117.

37. Abiodun, O.O.; Guan, H.; Post, V.E.A.; Batelaan, O. Comparison of MODIS and SWAT evapotranspiration over a complex terrain at different spatial scales. Hydrol. Earth Syst. Sci. 2018, 22, 2775-2794. [CrossRef]

38. Luo, Y.; Arnold, J.; Allen, P.; Chen, X. Baseflow simulation of SWAT model in an inland river basin in Tianshan Mountains, Northwest China. Hydrol. Earth Syst. Sci. Discuss. 2011, 8, 10397-10424. [CrossRef]

39. Arnold, J.G.; Srinivasan, R.; Muttiah, R.S.; Williams, J.R. Large area hydrologic modeling and assessment part I: Model development 1. JAWRA J. Am. Water Resour. Assoc. 1998, 34, 73-89. [CrossRef]

40. Golmohammadi, G.; Prasher, S.; Madani, A.; Rudra, R. Evaluating three hydrological distributed watershed models: MIKE-SHE, APEX, SWAT. Hydrology 2014, 1, 20-39. [CrossRef]

41. Pan, T.; Zuo, L.; Zhang, Z.; Zhao, X.; Liu, Y. Impact of Land Use Change on Water Conservation: A Case Study of Zhangjiakou in Yongding River. Sustainability 2020, 13, 22. [CrossRef]

42. Panagopoulos, Y.; Dimitriou, E. A Large-Scale Nature-Based Solution in Agriculture for Sustainable Water Management: The Lake Karla Case. Sustainability 2020, 12, 6761. [CrossRef]

43. Ryu, J.; Kang, H.; Choi, J.W.; Kong, D.S.; Gum, D.; Jang, C.H.; Lim, K.J. Application of SWAT-CUP for streamflow auto-calibration at Soyang-gang dam watershed. J. Korean Soc. Water Environ. 2012, 28, 347-358.

44. Khalid, K.; Ali, M.F.; Rahman, N.F.A.; Othman, Z.; Bachok, M.F. Calibration assessment of the distributed hydrologic model using SWAT-CUP. In Regional Conference on Science, Technology and Social Sciences (RCSTSS 2016); Springer: Berlin/Heidelberg, Germany, 2018; pp. 241-250.

45. Choi, H.S. Parameter estimation of SWAT model using SWAT-CUP in Seom-river experimental watershed. J. Korean Soc. Civ. Eng. 2013, 33, 529-536. [CrossRef]

46. Salimi, E.T.; Nohegar, A.; Malekian, A.; Hosseini, M.; Holisaz, A. Runoff simulation using SWAT model and SUFI-2 algorithm (case study: Shafaroud watershed, Guilan Province, Iran). Casp. J. Environ. Sci 2016, 14, 69-80.

47. Abbaspour, K.C. SWAT-CUP 2012 SWAT Calibration Uncertainty Program-A User Manual. Sci. Technol. $2014,106$.

48. Khalid, K.; Ali, M.F.; Rahman, N.F.A.; Mispan, M.R.; Haron, S.H.; Othman, Z.; Bachok, M.F. Sensitivity analysis in watershed model using SUFI-2 algorithm. Procedia Eng. 2016, 162, 441-447. [CrossRef]

49. Jajarmizadeh, M.; Harun, S.; Abdullah, R.; Salarpour, M. Using soil and water assessment tool for flow simulation and assessment of sensitive parameters applying SUFI-2 algorithm. Casp. J. Appl. Sci. Res. 2012, 2, 37-47.

50. Mehan, S.; Neupane, R.P.; Kumar, S. Coupling of SUFI 2 and SWAT for improving the simulation of streamflow in an agricultural watershed of South Dakota. Hydrol. Curr. Res. 2017, 8. [CrossRef]

51. Potter, C. Snowmelt timing impacts on growing season phenology in the northern range of Yellowstone National Park estimated from MODIS satellite data. Landsc. Ecol. 2020, 35, 373-388. [CrossRef]

52. Grippa, M.; Kergoat, L.; Toan, T.L.; Mognard, N.M.; Delbart, N.; L'Hermitte, J.; Vicente-Serrano, S.M. The impact of snow depth and snowmelt on the vegetation variability over central Siberia. Geophys. Res. Lett. 2005, 32. [CrossRef]

53. Molotch, N.P.; Guan, B.; Trujillo, E. Elevation-dependent controls on snowmelt partitioning and vegetation response inferred from satellite observations (Invited). In Proceedings of the AGU Fall Meeting Abstracts, San Francisco, CA, USA, 3-7 December 2012.

54. Cohen, J.; Pulliainen, J.; Ménard, C.B.; Johansen, B.; Oksanen, L.; Luojus, K.; Ikonen, J. Effect of reindeer grazing on snowmelt albedo and energy balance based on satellite data analyses. Remote Sens. Environ. 2013, 135, 107-117. [CrossRef]

55. Gómez-Giráldez, P.J.; Aguilar, C.; Polo, M.J.; Neale, C.M.U.; Maltese, A. NDVI sensitivity to the hydrological regime in semiarid mountainous environments. Proc. Spie Int. Soc. Opt. Eng. 2012, 8531, 103-104.

56. Zhao, X.; Tan, K.; Zhao, S.; Fang, J. Changing climate affects vegetation growth in the arid region of the northwestern China. J. Arid. Environ. 2011, 75, 946-952. [CrossRef]

57. Xin, Z.B.; Xu, J.X.; Zheng, W. Spatiotemporal variations of vegetation cover on the Chinese Loess Plateau (1981-2006): Impacts of climate changes and human activities. Sci. China Ser. D Earth Sci. 2008, 51, 67-78. [CrossRef]

58. Li, B.; Chen, Y.; Chen, Z.; Li, W.; Zhang, B. Variations of temperature and precipitation of snowmelt period and its effect on runoff in the mountainous areas of Northwest China. J. Geog. Sci. 2013, 23, 17-30. [CrossRef] 
59. Ma, Y.G.; Huang, Y.; Chen, X.; Li, Y.P.; Bao, A.M. Modelling Snowmelt Runoff under Climate Change Scenarios in an Ungauged Mountainous Watershed, Northwest China. Math. Prob. Eng. 2013, 2013, 808565. [CrossRef]

60. Duan, Y.; Meng, F.; Liu, T.; Huang, Y.; Luo, M.; Xing, W.; De Maeyer, P. Sub-Daily Simulation of Mountain Flood Processes Based on the Modified Soil Water Assessment Tool (SWAT) Model. Int. J. Environ. Res. Public Health 2019, 16, 3118. [CrossRef]

61. Liu, J.; Zhang, W.; Nie, N. Spatial Downscaling of TRMM Precipitation Data Using an Optimal Subset Regression Model with NDVI and Terrain Factors in the Yarlung Zangbo River Basin, China. Adv. Meteorol. 2018. [CrossRef]

62. Adosi, J.J. Seasonal variation of carbon dioxide, rainfall, NDVI and it's association to land degradation in Tanzania. In Climate and Land Degradation; Springer: Berlin/Heidelberg, Germany, 2007; pp. 373-389.

63. Zamri, N.; Abdullah, L. Flood control project selection using an interval type-2 entropy weight with interval type-2 fuzzy TOPSIS. AIP Conf. Proc. 2014, 1602, 62-68.

64. Franchini, M.; Lamberti, P. A flood routing Muskingum type simulation and forecasting model based on level data alone. Water Resour. Res. 1994, 30, 2183-2196. [CrossRef]

65. Fujita, K.; Takeuchi, N.; Aizen, V.; Nikittin, S. Glaciological observations on the plateau of Belukha Glacier in the Altai Mountains, Russia from. Bull. Glaciol. Res. 2004, 21, 57-64.

66. Bai, S.; Wang, L.; Shi, J.; LI, W. Runoff simulation for Kaidu river basin based on SWAT model. J. Arid Land Resour. Environ. 2013, 27, 79-84. [CrossRef]

67. Song, Q.; Mu, Z.; Jiang, H. Application of SWAT model in western area of Tianshan Mountain. J. Water Resour. Water Eng. 2013, $24,46-49$.

68. Xian-yong, M.; Xiao-nan, J.; Zhi-hui, L.; Xi, C.; Shi-feng, F. Study on snowmelt runoff under climate change effect in Tianshan mountain in China. Nat. Environ. Pollut. Technol. 2013, 12, 555.

69. Tiwari, S.; Kar, S.C.; Bhatla, R. Snowfall and Snowmelt Variability over Himalayan Region in Inter-annual Timescale. Aquat. Procedia 2015, 4, 942-949. [CrossRef]

70. Viglione, A.; Chirico, G.B.; Komma, J.; Woods, R.; Borga, M.; Blöschl, G. Generalised synthesis of space-time variability in flood response: Dynamics of flood event types. In Proceedings of the Egu General Assembly Conference, Vienna, Austria, 2-7 May 2010.

71. Serjantov, A.; Dingledine, R.; Syverson, P. From a Trickle to a Flood: Active Attacks on Several Mix Types. In International Workshop on Information Hiding; Springer: Berlin/Heidelberg, Germany, 2002.

72. Grillakis, M.G.; Tsanis, I.K.; Koutroulis, A.G. Application of the HBV hydrological model in a flash flood case in Slovenia. Nat. Hazards Earth Syst. Sci. 2010, 10, 2713-2725. [CrossRef]

73. Yuan, F.; Zhang, L.; Soe, K.M.W.; Ren, L.; Zhao, C.; Zhu, Y.; Jiang, S.; Liu, Y. Applications of TRMM- and GPM-Era MultipleSatellite Precipitation Products for Flood Simulations at Sub-Daily Scales in a Sparsely Gauged Watershed in Myanmar. Remote Sens. 2019, 11, 140. [CrossRef]

74. Jain, S.K.; Goswami, A.; Saraf, A.K. Assessment of snowmelt runoff using remote sensing and effect of climate change on runoff. Water Resour. Manag. 2010, 24, 1763-1777. [CrossRef]

75. Luo, Y.; Arnold, J.; Allen, P.; Chen, X. Baseflow simulation using SWAT model in an inland river basin in Tianshan Mountains, Northwest China. Hydrol. Earth Syst. Sci. 2012, 16, 1259-1267. [CrossRef]

76. Kjeldsen, T.R.; Rosbjerg, D. Comparison of regional index flood estimation procedures based on the extreme value type I distribution. Stoch. Environ. Res. Risk Assess. 2002, 16, 358-373. [CrossRef]

77. Li, D.; Qu, S.; Shi, P.; Chen, X.; Xue, F.; Gou, J.; Zhang, W. Development and Integration of Sub-Daily Flood Modelling Capability within the SWAT Model and a Comparison with XAJ Model. Water 2018, 10, 1263. [CrossRef]

78. Hoang, L.; Van Griensven, A.; Mynett, A. Enhancing the SWAT model for simulating denitrification in riparian zones at the river basin scale. Environ. Model. Softw. 2017, 93, 163-179. [CrossRef]

79. Sinnathamby, S.; Douglas-Mankin, K.R.; Craige, C. Field-scale calibration of crop-yield parameters in the Soil and Water Assessment Tool (SWAT). Agric. Water Manag. 2017, 180, 61-69. [CrossRef]

80. Zhang, X.; Srinivasan, R.; Debele, B.; Hao, F. Runoff simulation of the headwaters of the Yellow River using the SWAT model with three snowmelt algorithms. J. Am. Water Resour. Assoc. 2008, 44, 48-61. [CrossRef]

81. Hock, R. Temperature index melt modelling in mountain areas. J. Hydrol. 2003, 282, 104-115. [CrossRef]

82. Laudon, H.; Hemond, H.F.; Krouse, R.; Bishop, K. Oxygen 18 fractionation during snowmelt: Implications for spring flood hydrograph separation. Water Resour. Res. 2002, 38, 40-1-40-10. [CrossRef]

83. Hock, R. A distributed temperature-index ice- and snowmelt model including potential direct solar radiation. J. Glaciol. 1999, 45, 101-111. [CrossRef]

84. Jiang, X.; Wang, N.L.; He, J.Q.; Wu, X.B.; Song, G.J. A distributed surface energy and mass balance model and its application to a mountain glacier in China. Chin. Sci. Bull. 2010, 55, 2079-2087. [CrossRef]

85. Vilaysane, B.; Takara, K.; Luo, P.; Akkharath, I.; Duan, W. Hydrological stream flow modelling for calibration and uncertainty analysis using SWAT model in the Xedone river basin, Lao PDR. Procedia Environ. Sci. 2015, 28, 380-390. [CrossRef]

86. Mernild, S.H.; Liston, G.E. The Influence of Air Temperature Inversions on Snowmelt and Glacier Mass Balance Simulations, Ammassalik Island, Southeast Greenland. J. Appl. Meteorol. Climatol. 2010, 49, 47-67. [CrossRef]

87. Qi, J.; Li, S.; Jamieson, R.; Hebb, D.; Xing, Z.; Meng, F.-R. Modifying SWAT with an energy balance module to simulate snowmelt for maritime regions. Environ. Model. Softw. 2017, 93, 146-160. [CrossRef] 
88. Viglione, A.; Chirico, G.B.; Komma, J.; Woods, R.; Borga, M.; Blöschl, G. Quantifying space-time dynamics of flood event types. J. Hydrol. 2010, 394, 213-229. [CrossRef]

89. Yang, J.; Reichert, P.; Abbaspour, K.C.; Xia, J.; Yang, H. Comparing uncertainty analysis techniques for a SWAT application to the Chaohe Basin in China. J. Hydrol. 2008, 358, 1-23. [CrossRef]

90. Zhang, W.; Shen, Y.; Wang, N.; He, J.; Zhou, J. Investigations on physical properties and ablation processes of snow cover during the spring snowmelt period in the headwater region of the Irtysh River, Chinese Altai Mountains. Environ. Earth Sci. 2016, 75, 199. [CrossRef]

91. Ewing, M.E.; Reese, C.A.; Nolan, M.A. The potential effects of percolating snowmelt on palynological records from firn and glacier ice. J. Glaciol. 2014, 60, 661-669. [CrossRef]

92. Wu, X.; Che, T.; Li, X.; Wang, N.; Yang, X. Slower snowmelt in spring along with climate warming across the Northern Hemisphere. Geophys. Res. Lett. 2018, 45, 331-339. [CrossRef]

93. Huang, J.-B.; Wang, B.; Hinokidani, O.; Yamamoto, S. A distributed numerical rainfall-runoff model combined with snowmelt module. Adv. Water Sci. 2012, 23, 194-199.

94. Duan, Y.; Liu, T.; Meng, F.; Luo, M.; Frankl, A.; De Maeyer, P.; Bao, A.; Kurban, A.; Feng, X. Inclusion of Modified Snow Melting and Flood Processes in the SWAT Model. Water 2018, 10, 1715. [CrossRef]

95. Zhang, F.; Bai, L.; Li, L.; Wang, Q. Sensitivity of runoff to climatic variability in the northern and southern slopes of the Middle Tianshan Mountains, China. J. Arid Land 2016, 8, 681-693. [CrossRef]

96. Dou, Y.; Chen, X.; Bao, A.; Li, L. The simulation of snowmelt runoff in the ungauged Kaidu River Basin of TianShan Mountains, China. Environ. Earth Sci. 2011, 62, 1039-1045. [CrossRef]

97. Jain, S.K.; Jain, S.K.; Jain, N.; Xu, C. Hydrologic modeling of a Himalayan mountain basin by using the SWAT model. Hydrol. Earth Syst. Sci. 2017, 1-26. [CrossRef]

98. Smith, T.; Bookhagen, B.; Rheinwalt, A. Spatiotemporal patterns of High Mountain Asia's snowmelt season identified with an automated snowmelt detection algorithm, 1987-2016. Cryosphere 2017, 11, 2329. [CrossRef]

99. Wang, K.; Zhang, L.; Qiu, Y.; Ji, L.; Tian, F.; Wang, C.; Wang, Z. Snow effects on alpine vegetation in the Qinghai-Tibetan Plateau. Int. J. Digit. Earth 2015, 8, 58-75. [CrossRef]

100. McNeill, K.; Macdonald, K.; Singh, A.; Binns, A.D. Food and water security: Analysis of integrated modeling platforms. Agric. Water Manag. 2017, 194, 100-112. [CrossRef]

101. Zhao, Q.D.; Ye, B.S.; Ding, Y.J.; Zhang, S.Q.; Yi, S.H.; Wang, J.; Shangguan, D.H.; Zhao, C.C.; Han, H.D. Coupling a glacier melt model to the Variable Infiltration Capacity (VIC) model for hydrological modeling in north-western China. Environ. Earth Sci. 2013, 68, 87-101. [CrossRef]

102. Liu, S.Y.; Sun, W.X.; Shen, Y.P.; Li, G. Glacier changes since the Little Ice Age maximum in the western Qilian Shan, northwest China, and consequences of glacier runoff for water supply. J. Glaciol. 2003, 49, 117-124. [CrossRef]

103. Duan, Y.; Liu, T.; Meng, F.; Yuan, Y.; Luo, M.; Huang, Y.; Xing, W.; Nzabarinda, V.; De Maeyer, P.J.R.S. Accurate Simulation of Ice and Snow Runoff for the Mountainous Terrain of the Kunlun Mountains, China. Remote Sens. 2020, 12, 179. [CrossRef]

104. Hong, M.; Liu, Z.; Liu, Y. Energy balance of a snow cover and simulation of snowmelt in the western Tien Shan Mountains, China. Ann. Glaciol. 1992, 16, 73-78. [CrossRef]

105. Chen, Y.N.; Deng, H.J.; Li, B.F.; Li, Z.; Xu, C.C. Abrupt change of temperature and precipitation extremes in the arid region of Northwest China. Quat. Int. 2014, 336, 35-43. [CrossRef]

106. Grusson, Y.; Sun, X.; Gascoin, S.; Sauvage, S.; Raghavan, S.; Anctil, F.; Sáchez-Pérez, J.-M.J.J.o.H. Assessing the capability of the SWAT model to simulate snow, snow melt and streamflow dynamics over an alpine watershed. J. Hydrol. 2015, 531, 574-588. [CrossRef]

107. Le, B.T. An Application of Soil And Water Analysis Tool (Swat) for Water Quality of Upper Cong Watershed, Vietnam. Master Thesis, Asian Institute of Technology, Khlong Luang, Thailand, 2005.

108. Masuda, K.; Morinaga, Y.; Numaguti, A.; Ouchi, A. Seasonal variation of snow cover over the Northern Hemisphere: Progression of snowmelt. Proc. NIPR Symp. Polar Meteorol. Glaciol. 1990, 3, 107-108.

109. Pomeroy, J.; Fang, X.; Ellis, C. Sensitivity of snowmelt hydrology in Marmot Creek, Alberta, to forest cover disturbance. Hydrol. Process. 2012, 26, 1891-1904. [CrossRef]

110. Laidler, G.J.; Treitz, P.M.; Atkinson, D.M. Remote sensing of arctic vegetation: Relations between the NDVI, spatial resolution and vegetation cover on Boothia Peninsula, Nunavut. Arctic 2008, 61, 1-13. [CrossRef]

111. Reed, B.; Budde, M.; Spencer, P.; Miller, A. Integration of MODIS-derived metrics to assess interannual variability in snowpack, lake ice, and NDVI in southwest Alaska. Remote Sens. Environ. 2009, 113, 1443-1452. [CrossRef]

112. Ward, D.H.; Helmericks, J.; Hupp, J.W.; McManus, L.; Budde, M.; Douglas, D.C.; Tape, K. Multi-decadal trends in spring arrival of avian migrants to the central Arctic coast of Alaska: Effects of environmental and ecological factors. J. Avian Biol. 2016, 47, 197-207. [CrossRef]

113. Zheng, Z.; Wenxi, L.U.; Chu, H.B.; Cheng, W.G.; Ying, Z. Uncertainty analysis of hydrological model parameters based on the bootstrap method:A case study of the SWAT model applied to the Dongliao River Watershed, Jilin Province, Northeastern China. Sci. China Technol. Sci. 2014, 57, 219-229. [CrossRef]

114. Singh, V.; Bankar, N.; Salunkhe, S.S.; Bera, A.K.; Sharma, J. Hydrological stream flow modelling on Tungabhadra catchment: Parameterization and uncertainty analysis using SWAT CUP. Curr. Sci. 2013, 104, 1187-1199. 
115. Cao, Y.; Zhang, J.; Yang, M.; Lei, X.; Guo, B.; Yang, L.; Zeng, Z.; Qu, J.J.W. Application of SWAT model with CMADS data to estimate hydrological elements and parameter uncertainty based on SUFI-2 Algorithm in the Lijiang river basin, China. Water 2018, 10, 742. [CrossRef]

116. Luo, P.; Takara, K.; He, B.; Cao, W.; Yamashiki, Y.; Nover, D. Calibration and uncertainty analysis of SWAT model in a Japanese river catchment. J. Jpn. Soc. Civ. Eng. 2011,67, I_61-I_66. [CrossRef]

117. Jung, J.; Cho, S.; Lim, B.; Oh, T.; Ham, S.; Kim, K. Evaluation of the possibility of daily flow data generation from 8-day interval measured flow data using SWAT-CUP. J. Korean Soc. Water Environ. 2012, 28, 595-600.

118. Kumar, N.; Singh, S.K.; Srivastava, P.K.; Narsimlu, B. SWAT Model calibration and uncertainty analysis for streamflow prediction of the Tons River Basin, India, using Sequential Uncertainty Fitting (SUFI-2) algorithm. Modeling Earth Syst. Environ. 2017, 3, 30. [CrossRef]

119. Luo, N.; Mao, D.; Wen, B.; Liu, X. Climate Change Affected Vegetation Dynamics in the Northern Xinjiang of China: Evaluation by SPEI and NDVI. Land 2020, 9, 90. [CrossRef]

120. Xu, Y.; Yang, J.; Chen, Y. NDVI-based vegetation responses to climate change in an arid area of China. Theor. Appl. Climatol. 2016, 126, 213-222. [CrossRef] 